\title{
Facility Effluent Monitoring Plan Determinations for the 600 Area Facilities
}

Prepared for the U.S. Department of Energy Assistant Secretary for Environment, Safety and Health

\section{(28) Westinghouse \\ Wanford Company Richland, Washington}

Hantord Operations and Engineering Contractor for the

U.S. Department of Energy under Contract DE-AC06 87RL10930 


\section{LEGAL DISCLAIMER}

This report was prepared as an account of work sponsored by an agency of the Uniled States Government. Nelther the United States Government nor any agency thereof, nor any of their employees, nor any of their contractors, subcontractors or their employees, makes any warranty, express or implied, or assumes any legal liability or responsibility for the

accuracy, completeness, or any third party's use or the results of such use of any information, apparatus, product, or process disclosed, or represents that its use would not intringe privately owned rights. Reference herein to any specific commercial product, process, or service by trade name. llademark, manufaciurer, or otherwise, does nol necessarlly conslitute or iniply its endorsement, recommendation, or favoring by the Unifed States Government or any agency thereof or its contraclors or subcontractors. The views and opinions of authors expressed heroin do not necessarily slate or reflect those of the United States Government or any agency thereof.

This report has been reproduced from the best available copy. Available in paper copy and microliche.

Avallable to :he UI S Department of Energy and its contiaciors from

Oifice of Scienific and Technical Intormation

P. 0. Bux 62

Oak R.dge. TN 37831

(615) 576.8401

Avaliable to the public from the U.S. Department of Commerce National Technical Irformalion Service

5285 Port Royal Road

Springtield. VA 2216

(703) 487.4650

Printe: ir the United Slulus of America

DHSC:M-1 CHP (1.91) 
WHC-EP- -0443

DE92 002259

\section{Facility Effluent Monitoring Plan Determinations for the 600 Area Facilities}

\section{Environmental Assurance}

Date Published

August 1991

Prepared for the U.S. Department of Energy Assistant Secretary for Environment, Safety and Health

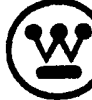




\section{APPROVAL}

Prepared by:

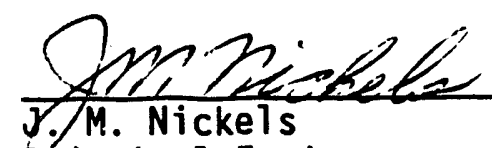

$\frac{8-29-91}{\text { Date }}$

Approved by:

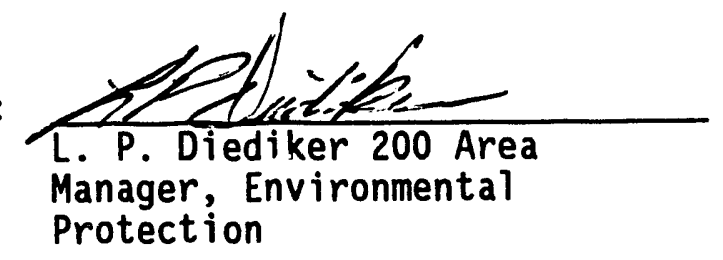

$$
\frac{9-3-4 /}{\text { Date }}
$$

Protection

Approved by:
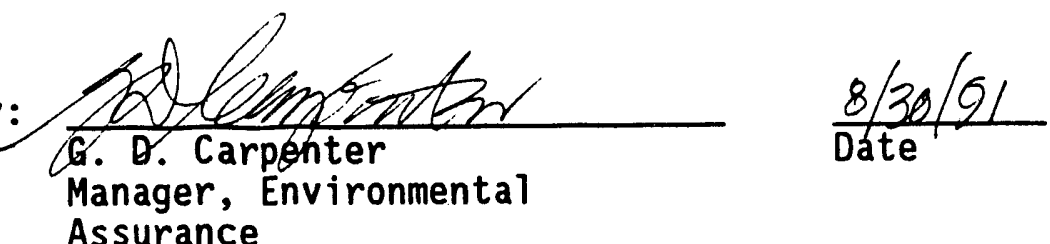

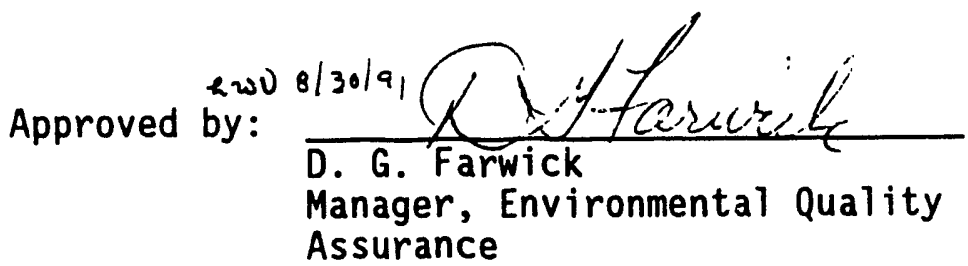

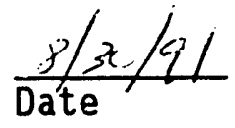

Approved by:

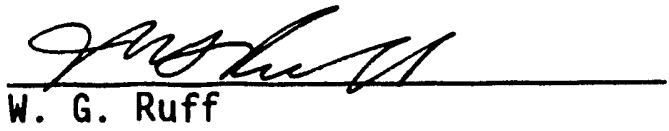

$\frac{9-3-9}{\text { Date }}$

Acting Director,

Facility Operations 
WHC-EP-0443

600 AREA FACILITIES

FACILITY EFFLUENT MONITORING PLAN DETERMINATIONS

\section{J. M. Nickels}

\section{ABSTRACT}

This document determines the need for Facility Effluent Monitoring Plans for Westinghouse Hanford Company's 600 Area facilities on the Hanford Site. The Facility Effluent Monitoring Plan determinations were prepared in accordance with A Guide For Preparing Hanford Site Facility Effluent Monitoring Plans (WHC 1991).

Five major Westinghouse Hanford Company facilities in the 600 Area were evaluated: the Purge Water Storage Facility, 212-N, $-P$, and $-R$ Facilities, the 616 Facility, and the 213-J\&K Storage Vaults. Of the five major facilities evaluated in the 600 Area, none will require preparation of a Facility Effluent Monitoring Plan. 
WHC-EP-0443

This page intentionally left blank. 
WHC-EP-0443

\section{CONTENTS}

PART 1 - 600 AREA PURGE WATER STORAGE FACILITY, FACILITY EFFLUENT MONITORING FLAN DETERMINATION.

PART 2 - 212-N, -P, AND - R FACILITIES, FACILITY EFFLUENT MONITORING PLAN DETERMINATION.

PART 3 - 616 FACILITY, FACILITY EFFLUENT MONITORING PLAN DETERMINATION

PART 4 - 213-J\&K STORAGE VAULTS, FACILITY EFFLUENT MONITORING PLAN DETERMINATION.

APPENDIX

UNIT DOSE CONVERSION FACTORS PREPARED BY PACIFIC NORTHWEST LABORATORY TO BE USED IN OFFSITE DOSE CALCULATIONS. 
WHC-EP-0443

This page intentionally left blank. 
WHC-EP-0443

PART 1

600 AREA PURGE WATER STORAGE FACILITY

FACILITY EFIFLUENT MONITORING PLAN

DETERMINATION 
WHC-EP-0443

This page intentionally left blank. 


\section{CONTENTS}

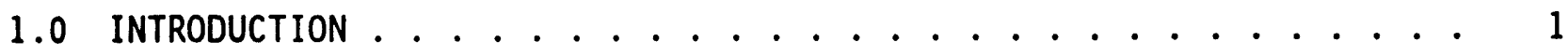

2.0 FACILITY DESCRIPTION . . . . . . . . . . . . . . 1

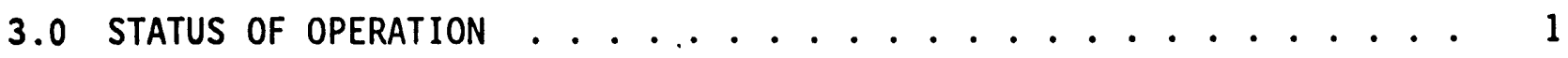

4.0 SOURCE TERM..$\ldots \ldots \ldots$

4.1 POTENTIAL UPSET-OPERATING CONDITIONS $\ldots \ldots \ldots$

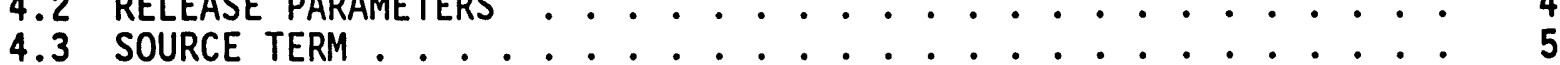

5.0 SUMMARY $\ldots \ldots \ldots \ldots \ldots \ldots$

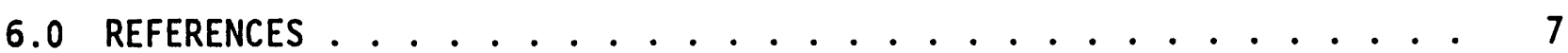

ATTACHMENT

1 DETERMINATION OF FACILITY EFFLUENT MONITORING PLAN REQUIREMENT . . . . . . . . . . . . . . . . Al-1 
WHC-EP-0443

\section{LIST OF TABLES}

1 Miscellaneous Chemical Constituents in Purge Water . . . . . . . . 2

2 Miscellaneous Radionuciides in Purge Water . . . . . . . . . . . 4

3 Toxicological Constituents for Project W-097 Compared to IDLH and PAG Values.................... . . . 6

4 Radiological Source Term for Project $W-097$. . . . . . . . . . . . 8

5 Radiological Consequences Compared with Westinghouse Hanford Company WHC-CM-4-46 Limits for a Low Hazard Facility . . . . . . . . . . . . 9 
WHC-EP-0443

\section{AREA PURGE WATER STORAGE FACILITY \\ FACILITY EFFLUENT MONITORING PLAN DETERMINATION}

\subsection{INTRODUCTION}

A Facility Effluent Monitoring Plan (FEMP) determination has been conducted for the Purge Water Storage Facility (PWSF) located within the 600 Area of the Hanford Site. This evaluation was performed using $A$ Guide For Preparing Ha: irued Site Facility Effluent Monitoring Plans (WHC 1991).

\subsection{FACILITY DESCRIPTION}

The PWSF consists of two large purge water modular storage tanks with secondary containment. The tanks contain purge water that originates from cleaning the water wells across the Hanford Site. The facility is located 1 , rtheast of the 200 East Area high-level burial grounds (submarine trench) and adjacent to the 216-B-3 Pond. The facility is classified as a low hazard non-nuclear facility according to the classification requirements of the Nonreactor Facility Safety Analysis Manual (WHC 1990).

\subsection{STATUS OF OPERATION}

The facility currently is operating as interim storage for the purge water from cleaning water wells across the Hanford Site. Future treatment and replacement of the two purge water modular torage tanks will be the proposed purge water surface impoundment (Project W-J97).

\subsection{SOURCE TERM}

The source term inventory is the same as the inventory identified in the hazard classification of Project $W-097$. The potential release mechanism for the facility is evaporation and subsequent aerosol generation. The chemically and radiologically contaminating constituents are identified in Tables 1 and 2. The facility is expected to store, before treatment, $29 \mathrm{Mgal}$ of purge water through 1998.

The evaporation mechanism will account for the release of the tritium, all of which is assumed to be present as tritiated water, as well as volatile organic liquid contaminants. The aerosol generation will be the cause of the release of the dissolved nonvolatile radioactive and nonradioactive components. 
WHC-EP-0443

Table 1. Miscellaneous Chemical Constituents in Purge Water. (2 sheets)

\begin{tabular}{|c|c|c|}
\hline \multirow{2}{*}{ Constituent } & \multicolumn{2}{|c|}{ (parts/billion) } \\
\hline & Maximu:n & Average \\
\hline Acetone & 110 & 5 \\
\hline Aluminum, filtered & 570 & 180 \\
\hline Aluminum & 1,100 & 60 \\
\hline Ammonium & 250 & $370 * *$ \\
\hline Arsenic & 51 & -- \\
\hline Barium & 255 & 53 \\
\hline Barium, filtered & 20 & $45 \star \star$ \\
\hline Benzane & 49 & --- \\
\hline Beryllium & 8 & --- \\
\hline Bis(2-ethylhexy1)phthalate & 29 & 2 \\
\hline Cadmium & 20 & 1 \\
\hline Calcium & 64,000 & 57,400 \\
\hline Carbon tetrachloride & 8,100 & 20 \\
\hline Chloride & 34,000 & 23,000 \\
\hline Chloroform & 1,650 & $<1$ \\
\hline Chromium & 1,690 & 31 \\
\hline Copper & 274 & 4 \\
\hline Cyanide & 1,690 & 10 \\
\hline 1,2 Dichloroethane & 6 & 5 \\
\hline Fluoride & 12,800 & 730 \\
\hline Iron, filtered & 600 & 67 \\
\hline Iron & $1,600 *$ & 120 \\
\hline Lead, filtered & 11 & 5 \\
\hline Lead & 132 & 2 \\
\hline Magnesium & 21,000 & 13,000 \\
\hline Manganese, filtered & 30 & 7 \\
\hline Manganese & 49 & 4 \\
\hline Mercury & 0.54 & --- \\
\hline Methylene chloride & 1,800 & 120 \\
\hline $\mathrm{N}$-nitrosodimethyl amine & 40 & 3 \\
\hline Nickel, filtered & 20 & 11 \\
\hline Nickel & 518 & 4 \\
\hline Nitrate & $2,810,000$ & 93,200 \\
\hline
\end{tabular}


Table 1. Miscellaneous Chemical Constituents in Purge Water. ( 2 sheets)

\begin{tabular}{|c|c|c|}
\hline \multirow{2}{*}{ Constituent } & \multicolumn{2}{|c|}{ (parts/billion) } \\
\hline & Maximum & Average \\
\hline PC3 & 23.8 & --- \\
\hline Perchloroethylene & 52 & 8 \\
\hline Phenol & 8 & 1 \\
\hline Phosphate & 11,000 & 1,150 \\
\hline Potassium & 7,300 & $7,600 * *$ \\
\hline Selenium & 54 & 1 \\
\hline Silver & 25 & --- \\
\hline Sodium, filtered & 94,000 & 19,500 \\
\hline Sodium & 93,000 & 27,500 \\
\hline Strontium, filtered & 470 & 311 \\
\hline Strontium & 340 & 249 \\
\hline Sulfate & 72,000 & $90,000 * *$ \\
\hline Sulfide & 1,350 & --- \\
\hline Total organic halogen & 1,600 & 70 \\
\hline Total alkalinity & 593,000 & 89,000 \\
\hline Total organic carbon & 1,800 & 830 \\
\hline Trans-1,2-dichloroethene & 70 & 9 \\
\hline 1,1,1-trichloroethane & 120 & 8 \\
\hline Trichloroethene & 38 & 8 \\
\hline Natural uranium & 16,600 & 67 \\
\hline Vanadium & 40 & 18 \\
\hline Zinc & 240 & 87 \\
\hline
\end{tabular}

*A spurious analysis of $222,000 \mathrm{ppb}$ iron was not included. **The average value is shown as higher than the maximum value in the data source. 
Table 2. Miscellaneous Radionuclides in Purge Water.

\begin{tabular}{|c|c|c|}
\hline \multirow{2}{*}{ Constituent } & \multicolumn{2}{|c|}{$(p C i / L)$} \\
\hline & Maximum & Average \\
\hline${ }^{3} \mathrm{H}$ & $14,000,000$ & 85,000 \\
\hline${ }^{14} \mathrm{C}$ & $<700$ & --- \\
\hline${ }^{60} \mathrm{Co}$ & 550 & 4 \\
\hline${ }^{63} \mathrm{Ni}$ & $<3,000$ & -- \\
\hline${ }^{90} \mathrm{Sr}$ & 23,000 & 24 \\
\hline${ }^{99} \mathrm{Tc}$ & 37,000 & 239 \\
\hline${ }^{103} \mathrm{Ru}$ & $<500$ & $\ldots$ \\
\hline${ }^{106} \mathrm{Ru}$ & 900 & 3 \\
\hline${ }^{125} \mathrm{Sb}$ & $<500$ & 4 \\
\hline${ }^{129} \mathrm{I}$ & 90 & 3 \\
\hline${ }^{131} I$ & 29,000 & 202 \\
\hline${ }^{137} \mathrm{Cs}$ & 2,500 & 1 \\
\hline${ }^{226} \mathrm{Ra}$ & 4 & --- \\
\hline${ }^{235} \mathrm{U}$ & 12,000 & 40 \\
\hline${ }^{238} \mathrm{Pu}$ & 0.4 & -- \\
\hline $239 / 240 \mathrm{Pu}$ & 72 & --- \\
\hline${ }^{241} \mathrm{Am}$ & $<0.3$ & -- \\
\hline
\end{tabular}

\subsection{POTENTIAL UPSET-OPERATING CONDITIONS}

No potential upset-operating conditions have been identified or deemed credible.

\subsection{RELEASE PARAMETERS}

The release of material by evaporation is based on evaporation pan data from the Prosser Agriculture Experiment Station. Evaporation rates for the Hanford Site can be expected to be $40 \mathrm{in}$. annually with a peak of $12 \mathrm{in./mo}$ in summer.

Conservative aerosol generation rates have been experimentally determined by Pacific Northwest Laboratory. The amount recommended for aerosol generated by gas bubbling through solution is 1 volume of liquid for every $10^{7}$ volumes of vapor/gas. 
WHC-EP-0443

\subsection{SOURCE TERM}

The toxicological source term is estimated assuming the release of volatile organic components occurs as the water is evaporated. Ideal solution behavior is assumed so the organic components will escape in the same relative proportion as they exist in the liquid phase.

The aerosol mechanism and subsequent release have not been calculated because using the conservative partition factor (ratio of liquid volume in the vapor/gas to the vapor/gas volume) of $10^{-7}$ gives a 7 crder of magnitude reduction in the concentration found in the basin and is too low to be considered further.

For the toxicological dose estimate, the source term release rate for any volatile organic component is derived by multiplying the evaporation rate by the fraction in the liquid phase. The result is a release rate (Q) for the component.

The concentration at the receptor can be estimated using the atmospheric dispersion factor of the form

$$
E / Q=L S D F
$$

where

$$
\begin{aligned}
E & =\text { The concentration at the point of interest } \\
Q & =\text { The emission rate } \\
\text { LSDF } & =\text { The location-specific dispersion factor. }
\end{aligned}
$$

Rearrangement then permits solution for $E$ if the LSDF and $Q$ are known. Table 2 shows the organic concentrations for the substances considered. For the purposes of this analysis, carbon tetrachloride was the only constituent examined because its concentration in the liquid was closest to its protective action guideline (PAG) value.

The radiological source term is generated from both the evaporation and aerosol mechanism. The evaporation is considered because the tritium concentration in the purge water is assumed to exist as tritiated water. The tritium concentration is estimated using the maximum tritium concentration shown in Table 3 and multiplying by the total volume of purge water expected to be evaporated. The other radionuclides expected to be released by aerosol mechanism are estimated bj multiplying the aerosol release volume by the concentrations of nuclides in the last evaporation volume (a conservative estimate would be the total nuclide quantity in the 1998 volume of $3,408,000 \mathrm{gal}$ ). 
Table 3. Toxicological Constituents for Project W-097 Compared to IDLH ${ }^{1}$ and $P A G^{2}$ Values.

\begin{tabular}{|l|c|c|c|}
\hline \multicolumn{1}{|c|}{ Component } & $\begin{array}{c}\text { Concentration } \\
\left(\mathrm{ppm}^{3}\right)\end{array}$ & $\begin{array}{c}\text { IDLH } \\
(\mathrm{ppm})\end{array}$ & $\begin{array}{c}\text { PAG } \\
(\mathrm{ppm})\end{array}$ \\
\hline Acetone & 0.11 & 20,000 & 10,000 \\
\hline Ammonia & 0.25 & 500 & 250 \\
\hline Benzene & 0.049 & 2,000 & 1,000 \\
\hline Bis(2-ethylhexyl)phthalate & 0.029 & $\star$ & 150 \\
\hline Carbon tetrachloride & 8.1 & 300 & 500 \\
\hline Chloroform & 1.65 & 1,000 & 2,500 \\
\hline Methylene chloride & 1.8 & 5,000 & $\star \star$ \\
\hline N-Nitrosodimethylamine & 0.04 & $\star$ & 50 \\
\hline Perchloroethylene & 0.052 & $*$ & 50 \\
\hline Phenol & 0.008 & 100 & 500 \\
\hline Trichloroethene & 0.038 & $*$ & 2,000 \\
\hline $1,1,1$ Trichloroethane & 0.12 & 1,000 & 2,000 \\
\hline 1,2 Dichloroethane & 0.006 & $*$ & $*$ \\
\hline 1,2 Trans-Dichloroethene & 0.07 & & $*$ \\
\hline
\end{tabular}

Immediately dangerous to life or health.

${ }_{3}^{2}$ Protective action guideline.

${ }^{3}$ Parts per million.

*IDLH values not 1isted. National Institute of Safety and Health recommends that the substance be treated as a potential human carcinogen. $\star * P A G$ values not listed for these compounds. 
The nuclides and quantities estimated to be released over a l-yr period are shown in Table 4.

Table 5 shows the calculated results of the radiological consequences compared with the safety analysis limits. These calculations are available on file with the cognizant engineer.

Concentrations of chemical constituents at the maximally exposed individual onsite and offsite shows Project W-097 to be a low hazard with regard to toxicological exposure.

The radiological and toxicological doses to offsite and onsite maximally exposed individuals are below limits for a low hazard facility.

The annual effective dose equivalent (EDE) for onsite individuals for tritium, the only credible source term inventory, is equal to $3.2 \times 10^{-4}$ rem. For the maximally exposed offsite individual, the annual inhalation EDE is $1.5 \times 10^{-5} \mathrm{rem}$. The annual ingestion EDE is $3.9 \times 10^{-6} \mathrm{rem}$.

\subsection{SUMMARY}

Because of the standby maintenance condition and limited source term inventory for radioactive (tritium) and hazardous materials (carbon tetrachloride) with minimal offsite dose consequences, a FEMP is not required.

\subsection{REFERENCES}

Napier, B. A., R. A. Peloquin, D. L. Strenge, and J. V. Ramsde11, 1988, GENII - The Hanford Environmental Radiation Dosimetry Software System, PNL-6584, Vols. 1-3, Pacific Northwest Laboratory, Richland, Washington.

WHC, 1990, Nonreactor Facility Safety Analysis Manual, WHC-CM-4-46-Rel 15, Westinghouse Hanford Company, Richland, Washington.

WHC, 1991, A Guide for Preparing Hanford Site Facility Effluent Monitoring Plans, WHC-EP-0438, Westinghouse Hanford Company, Richland, Washington. 
Table 4. Radiological Source Term for Project W-097 (1-Yr Release).

\begin{tabular}{|l|c|}
\hline \multicolumn{1}{|c|}{ Radionuclide } & $\mathrm{Ci}$ \\
\hline${ }^{3} \mathrm{H}$ & $1.5 \mathrm{E}+02$ \\
\hline${ }^{14} \mathrm{C}$ & $3.3 \mathrm{E}-04$ \\
\hline${ }^{60} \mathrm{Co}$ & $2.6 \mathrm{E}-04$ \\
\hline${ }^{63} \mathrm{Ni}$ & $1.4 \mathrm{E}-03$ \\
\hline${ }^{90} \mathrm{Sr}$ & $1.1 \mathrm{E}-02$ \\
\hline${ }^{99} \mathrm{TC}$ & $2.0 \mathrm{E}-02$ \\
\hline${ }^{103} \mathrm{Ru}$ & $2.4 \mathrm{E}-04$ \\
\hline${ }^{106} \mathrm{Ru}$ & $4.3 \mathrm{E}-04$ \\
\hline${ }^{125} \mathrm{Sb}$ & $2.4 \mathrm{E}-04$ \\
\hline${ }^{129} \mathrm{I}$ & $4.3 \mathrm{E}-05$ \\
\hline${ }^{131} \mathrm{I}$ & $1.4 \mathrm{E}-02$ \\
\hline${ }^{137} \mathrm{Cs}$ & $1.2 \mathrm{E}-03$ \\
\hline${ }^{234} \mathrm{U}$ & $5.0 \mathrm{E}-03$ \\
\hline${ }^{238} \mathrm{Pu}$ & $1.9 \mathrm{E}-07$ \\
\hline${ }^{239} \mathrm{Pu}$ & $3.5 \mathrm{E}-05$ \\
\hline${ }^{241} \mathrm{Am}$ & $1.4 \mathrm{E}-07$ \\
\hline${ }^{226} \mathrm{Ra}$ & $1.9 \mathrm{E}-06$ \\
\hline
\end{tabular}

NOTE: Radon-226 was not included in the GENII (Napier et al. 1988) input decks because previous runs showed the nuclide to be an insignificant contributor to the receptor's dose. 
Table 5. Radiological Consequences Compared with Westinghouse Hanford Company WHC-CM-4-46 (WHC 1990) Limits for a Low Hazard Facility.

\begin{tabular}{|c|c|}
\hline \multicolumn{2}{|c|}{ ONSITE } \\
\hline Radiological limit: & $\begin{array}{l}5 \text { rem EDE, } 50 \text { rem to } \\
\text { the max. organ }\end{array}$ \\
\hline$x / Q$ & $=1.76 \mathrm{E}-06 \mathrm{sec} / \mathrm{m}^{3}$ \\
\hline Distance & $=1,267.1 \mathrm{~m}$ \\
\hline Direction & $=$ South-southeast \\
\hline EDE & $\begin{array}{l}=3.2 \text { E-04 rem inhalation and } \\
\text { submersion }\end{array}$ \\
\hline Max. organ (lung) & $\begin{array}{l}=2.6 \text { E-03 rem committed dose } \\
\text { equivalent }\end{array}$ \\
\hline \multicolumn{2}{|c|}{ OFFSITE } \\
\hline Radiological limit: & $\begin{array}{c}0.5 \text { rem EDE, } 5 \text { rem to } \\
\text { the m.ax. organ }\end{array}$ \\
\hline$x / Q$ & $=8.16 \mathrm{E}-08 \mathrm{sec} / \mathrm{m}^{3}$ \\
\hline Distance & $=15,557 \mathrm{~m}$ \\
\hline Direction & $=$ East \\
\hline \multicolumn{2}{|c|}{ INHALATION AND SUBMERSION } \\
\hline EDE & $\begin{array}{l}=1.5 \mathrm{E}-05 \text { rem inhalation and } \\
\text { submersion }\end{array}$ \\
\hline Max. organ (lung) & $\begin{array}{l}=1.2 \text { E-04 rem committed dose } \\
\text { equivalent }\end{array}$ \\
\hline \multicolumn{2}{|c|}{ INGESTION AND GROUND SHINE } \\
\hline EDE & $=6.5$ E-06 rem cumulative dose \\
\hline Max. organ (thyroid) & $=3.4$ E-05 rem cumulative dose \\
\hline
\end{tabular}


WHC-EP-0443

This page intentionally left blank. 
WHC-EP-0443

ATTACHMENT 1

DETERMINATION OF FACILITY EFFLUENT MONITORING PLAN REQUIREMENT

Al-1 
WHC-EP-0443

This page intentionally left blank.

Al-2 


\section{ATTACHMENT 1}

DETERMINATION OF FACILITY EFFLUENT MONITORING PLAN REQUIREMENT

FACILITY Purge Water Storage Facility DISCHARGE POINT Storage Tanks

FACILITY INVENTORY AT RISK OF RADIOACTIVE MATERIALS

\begin{tabular}{|c|c|c|c|c|c|}
\hline Radionuclide & Physi & Chemical & Quantity & Quantity & Projected \\
\hline & Form & (Curies) & Rele & ased & (mrem) \\
\hline
\end{tabular}

1. ${ }^{3} \mathrm{H}$ qaseous/tritiated $1.5 \mathrm{E}+02 \quad 1.5 \mathrm{E}+02 \quad \mathrm{EDE}$ (1 ung) $1.5 \mathrm{E}-05$ (rem)

2. water EDE(thyroid) $6.5 \mathrm{E}-06(\mathrm{rem})$

4 .

Total

FACILITY INVENTORY AT RISK OF NONRADIOACTIVE HAZARDOUS MATERIALS

$\begin{array}{lccc}\begin{array}{l}\text { Regulated } \\ \text { Material }\end{array} & \begin{array}{c}\text { Quantity } \\ \text { (lbs) }\end{array} & \begin{array}{c}\text { Quantity } \\ \text { Released }\end{array} & \begin{array}{c}\text { Reportable } \\ \text { Quantity (1bs) }\end{array}\end{array}$

1. tetrachloride

$8.1 \mathrm{ppm}$

5,000 $<R Q$

2.

3.

4.

\section{Identification of Reference Material}

The hazard classification of the purge water surface impoundment (Project $W-097)$

If the total projected dose from radionuclide exceeds 0.1 mrem ede from any one discharge point or if any one regulated material discharged from a

facility exceeds $100 \%$ of a reportable quantity or a permitted quantity, a FEMP is required for that facility. Check the appropriate space below.

FEMP is required

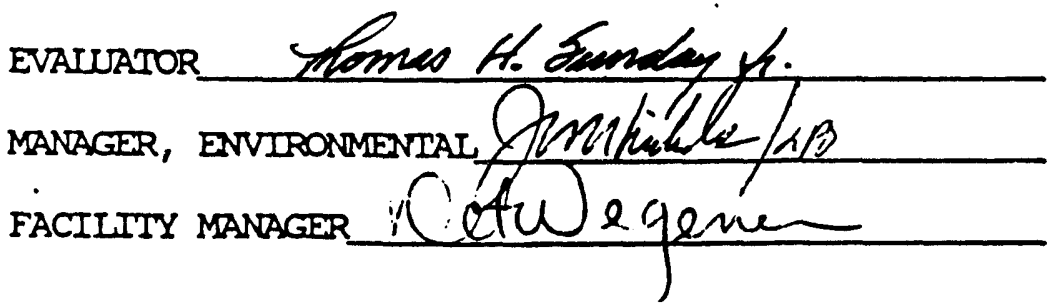

FEMP is not required $\underline{X}$ DATE_ $|-2-9|$ DATE $|-9-9|$ DATE $1 / 9 / 91$ 
WHC-EP-0443

This page intentionally left blank.

A1-4 
WHC-EP-0443

\author{
PART 2 \\ 212-N, -P, AND -R FACILITIES \\ FACILITY EFFLUENT MONITORING PLAN \\ DETERMINATION
}


WHC-EP-0443

This page intentionally left blank. 
WHC-EP-0443

\section{CONTENTS}

1.0 INTRODUCTION . . . . . . . . . . . . . . . . . . . . . 1

2.0 FACILITY DESCRIPTION/STATUS OF OPERATION . . . . . . . . . . . 1

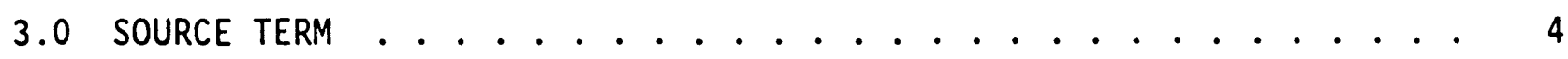

4.0 POTENTIAL UPSET-OPERATING CONDITIONS . . . . . . . . . . . . . . 4

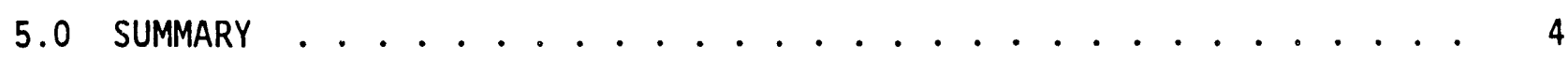

6.0 REFERENCES ......................... . . 5

\section{ATTACHMENT}

1 DETERMINATION OF FACILITY EFFLUENT MONITORING PLAN

REQUIREMENT. . . . . . . . . . . . . . . . . . . A $\mathrm{Al} 1$ 
WHC-EP-0443

\section{LIST OF TABLES}

1 Radionuclide Inventory for $218-\mathrm{N}-1 \ldots \ldots 2$

2 Waste Information Data System Radionuclide Inventory ....... 3 
212-N, -P, AND -R FACILITIES

FACILITY EFFLUENT NONITORING PLAN DETERMINATIONS

\subsection{INTRODUCTION}

The Westinghouse Hanford Company's (Westinghouse Hanford) Electrical Utilities function is responsible for determining Facility Effluent Monitoring Plan (FEMP) applicability to the 212-P Facility. Pacific Northwest Laboratory (PNL) is responsible for determining FEMP applicability to the $212-\mathrm{N}$ and $-R$ Facilities. Determining the need for a FEMP was conducted in accordance with $A$ Guide For Preparing Hanford Site Facility Effl'rent Monitoring Plans (WHC 1991).

\subsection{FACILITY DESCRIPTION/STATUS OF OPERATION}

There are three identical buildings (212-N, $-P$, and $-R$ ) located north of the electrical substation in the Separations Area north of Route 2, halfway between the 200 East and 200 West Areas, called the Metal and Fuel Storage Basin Facilities. These were designed for underwater storage of irradiated reactor fuel elements (slugs). Each building is comprised of two main sections and a heater room. Each section has a concrete foundation and roof and walls constructed of concrete and concrete block. Exterior dimensions of the high roof section are $27 \mathrm{ft}$ by $74 \mathrm{ft}$ by $30 \mathrm{ft}$ high. The low roof section is $49 \mathrm{ft}$ by $72 \mathrm{ft}$ by $12 \mathrm{ft}$ high. The heater room is $14 \mathrm{ft}$ by $26 \mathrm{ft}$ by $12 \mathrm{ft}$ high. The total area of each building is $5,970 \mathrm{ft}^{2}$; the storage basin is $3,300 \mathrm{ft}^{2}$ and the transfer basin is $400 \mathrm{ft}^{2}$.

These facilities were used from 1944 through 1952 for fuel storage. In 1970 PNL and Westinghouse Hanford moved 24 crates of various contaminated equipment to tile 212-N and $-\mathrm{R}$ Buildings. Sometime during 1971 and 1972 nine of the crates were moved to a 200 West industrial burial ground, the 231-Z Building, and the 308 Building. All remaining crates in the 212-R Building were transferred to the 212-N Building. The remaining 15 crates have been stored in $212-\mathrm{N}$ since 1972 . The crates or boxes are stacked inside the building and covered with a mound of commercial insulating material. See Table 1 for current inventory.

The 212-P Building has been used only as a storage facility for approximately $5.03 \mathrm{~m}^{3}$ of liquid and solid hazardous waste. This site is not included in une Hanford Federal Facility Agreement and Consent Order (Ecology et al. 1990) action plan. See Table 2 for current inventory. 
Table 1. Radionuclide Inventory for 218-N-1 (in Curies).

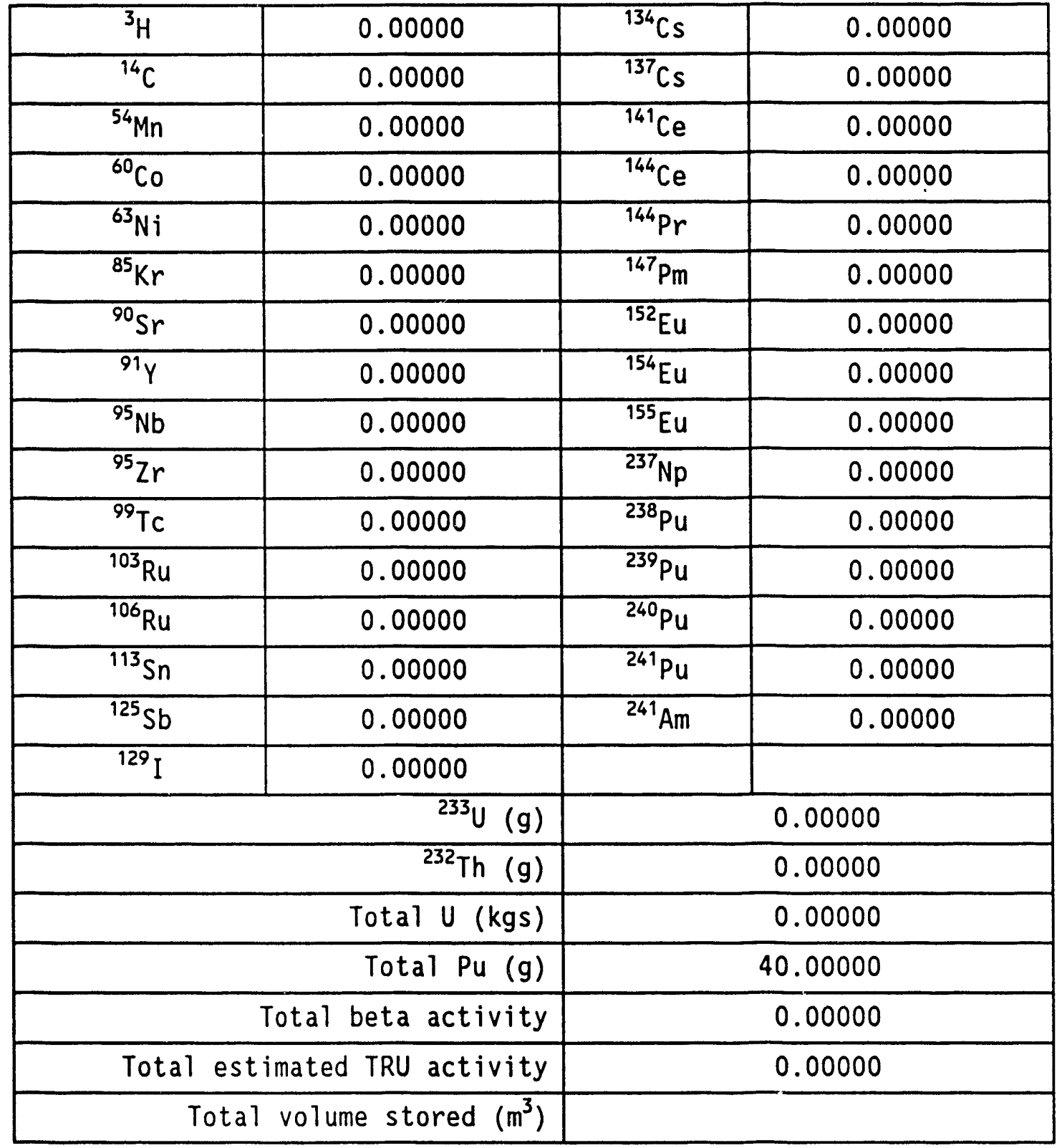

These values are decayed through December 31, 1988.

TRU = transuranic. 
Table 2. Waste Information Data System Radionuclide Inventory (in Curies).

\begin{tabular}{|c|c|c|c|c|c|}
\hline \multicolumn{6}{|c|}{ Site Name: $\quad 212-P$ Storage Facility } \\
\hline \multicolumn{6}{|c|}{ Operable Unit: $200-\mathrm{NO}-1$} \\
\hline \multicolumn{6}{|c|}{ Bibliography for the following individual isotopes: [404] } \\
\hline${ }^{3} \mathrm{H}$ & & ${ }^{113} \mathrm{Sn}$ & & ${ }^{234} \mathrm{U}$ & \\
\hline${ }^{14} \mathrm{C}$ & & ${ }^{125} \mathrm{Sb}$ & & 23 & \\
\hline${ }^{22} \mathrm{Na}$ & & ${ }^{129} \mathrm{I}$ & & ${ }^{237} \mathrm{~Np}$ & \\
\hline${ }^{54} \mathrm{Mn}$ & & ${ }^{134} \mathrm{Cs}$ & & ${ }^{238} \mathrm{U}$ & \\
\hline${ }^{58} \mathrm{Co}$ & & ${ }^{137} \mathrm{Cs}$ & 0.24450 & ${ }^{238} \mathrm{Pu}$ & 0.05984 \\
\hline${ }^{59} \mathrm{Fe}$ & & ${ }^{141} \mathrm{Ce}$ & & ${ }^{239} \mathrm{Pu}$ & 1.25180 \\
\hline${ }^{60} \mathrm{Co}$ & & ${ }^{144} \mathrm{Ce}$ & & ${ }^{240} \mathrm{Pu}$ & 0.31020 \\
\hline${ }^{63} \mathrm{Ni}$ & & ${ }^{147} \mathrm{Pm}$ & & ${ }^{241} \mathrm{Pu}$ & 0.86680 \\
\hline${ }^{85} \mathrm{Kr}$ & & ${ }^{152} \mathrm{Eu}$ & & ${ }^{241} \mathrm{Am}$ & 0.45540 \\
\hline${ }^{90} \mathrm{Sr}$ & 0.22290 & ${ }^{154} \mathrm{Eu}$ & & ${ }^{242} \mathrm{Pu}$ & 0.00002 \\
\hline${ }^{95} \mathrm{Zr}$ & & ${ }^{155} \mathrm{Eu}$ & & ${ }^{243} \mathrm{Am}$ & \\
\hline${ }^{99} \mathrm{TC}$ & & ${ }^{232} \mathrm{Th}$ & & ${ }^{245} \mathrm{Cm}$ & \\
\hline${ }^{106} \mathrm{Ru}$ & 0.00001 & ${ }^{233} U$ & & & \\
\hline \multicolumn{2}{|c|}{ Inventory Total Pu: } & 2.48866 & \multicolumn{3}{|c|}{$\begin{array}{l}\text { (summation of } \mathrm{Pu} \text { isotopes } \\
\text { listed above) }\end{array}$} \\
\hline \multicolumn{2}{|c|}{ Inventory Total U: } & 0.00000 & \multicolumn{3}{|c|}{$\begin{array}{l}\text { (summation of } U \text { isotopes } \\
\text { listed above) }\end{array}$} \\
\hline \multicolumn{2}{|c|}{ Reported Total Pu: } & & \multicolumn{3}{|l|}{ grams } \\
\hline \multicolumn{2}{|c|}{ Reported Total U: } & 0.00000 & \multicolumn{3}{|l|}{ kilograms } \\
\hline
\end{tabular}

The above values are decayed through December 31, 1988. 


\subsection{SOURCE TERM}

The 212-N and $-R$ Storage Buildings have been active since 1970. The 212-N Building stores approximately 15 large wooden boxes containing hoods and equipment formerly used for fabrication of fuels for the Plutonium Recycle Test Reactor. The boxes are still stacked inside the building. The waste is contaminated with an estimated $40 \mathrm{~g}$ of plutonium. No other inventory of radioactive material exists in this facility. The waste is owned by PNL.

Since 1982 the 212-P Building has held polychlorinated biphenyls (PCB), and PCB-contaminated waste (nonradioactive) in temporary (up to 9 mo) storage, according to the Toxic Substances Control Act (TSCA). Radioactively contaminated PCBs are stored in another area of this unit. Waste types include $854 \mathrm{~kg}$ of oil less than $50 \mathrm{ppm}$ PCBs; $1,348 \mathrm{~kg}$ of $0 i 1$ greater than 50 ppm PCBs; 703 light ballasts containing PCBs stored in overpacks; $1,159 \mathrm{~kg}$ of 0 il greater than $500 \mathrm{ppm} ; 7$ sealed transformers with less than $30 \mathrm{ppm}$ PCBs 0i1; 1 capacitor with 1\% PCB oil; 11 low-voltage capacitors with greater than $50 \mathrm{ppm}$ PCB oil; and $42 \mathrm{~kg}$ regulated solvents with greater than $500 \mathrm{ppm}$ PCB. Drained items as allowed under the TSCA occasionally are stored on an asphalt pad at the southeast corner of the building.

At any one time no more than 41,000 1b of 1iquid and solid PCB waste will be stored at the 212-P Building. As required by TSCA regulations, no drains are present and total containment is provided in the event of a container failure.

Shipments are made from the facility quarterly or as necessary to comply with the TSCA 9-mo storage limitation. Monthly documented inspections are performed by utilities personnel. This facility meets TSCA requirements for temporary storage of PCBs.

There are no radioactive materials stored at the 212-P Building. The 212-P Building has no water supply and no sewer drains as potential release points.

\subsection{POTENTIAL UPSET-OPERATING CONDITIONS}

No potential upset conditions have been identified or deemed credible.

\subsection{SUMMARY}

There are no processes at the 212-P, $-N$, and $-R$ Buildings that could release any reportable quantities of hazardous or radioactive materials. These buildings are used as temporary storage where waste is staged before offsite disposal. A FEMP is not required. 


\subsection{REFERENCES}

Ecology, EPA, and DOE, 1990, Hanford Federal Facility Agreement and Consent Order, Vol. 1 and 2, Washington State Department of Ecology, U.S. Environmental Protection Agency, and U.S. Department of Energy, 01 ympia, Washington.

Toxic Substances Control Act of 1976, 15 USC 2601 et seq.

WHC, 1991, A Guide for Preparing Hanford Site Facility Effluent Monitoring Plans, WHC-EP-0438, Westinghouse Hanford Company, Richland, Washington. 
WHC-EP-0443

This page intentionally left blank. 
WHC-EP-0443

\section{ATTACHMENT 1}

DETERMINATION OF FACILITY EFFLUENT MONITORING PLAN REQUIREMENT

A1-1 
WHC-EP-0443

This page intentionally left blank. 


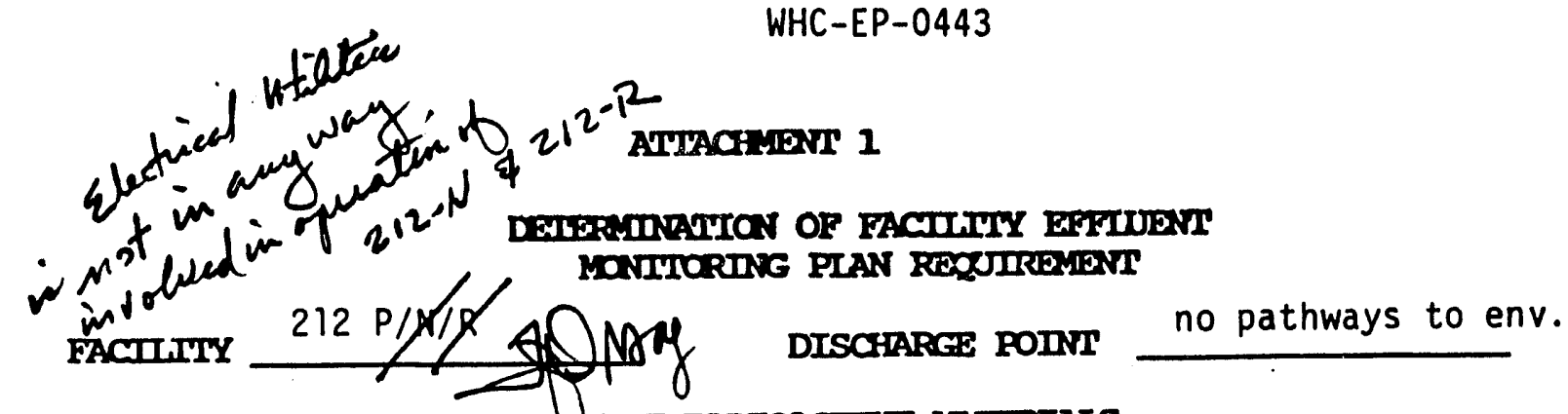

FACTIIIY INVENTORY AT RISS OF RADIOACTIVE MATERTALS

Radionuclide Physical/Chemical Quantity Quantity Projected Dose

1.

Form

(Curies) Released

(mrem)

2 .

No Radionuclides

3.

4.

Total

FACIIITIY IIVENIORY ATT RTSK OF NONRADIOACTIVE HAZARDOUS MATERLATS

$\begin{array}{lcccc}\text { Regulated } & \text { Quantity } & \text { Quantity } & \text { Reportable } & \text { of of Reportable } \\ \text { Material } & \text { (lbs) } & \text { Released } & \text { quantity (lbs) } & \text { quantity/Year }\end{array}$

1. $\quad$ (regulated by TSCA)

2.

3.

4 .

Identification of Reference Material

If the total projected dose from radionuclides exceeds 0.1 mrem ede fran any one discharge point or if any one regulated material discharged from a facility exceeds $100 \%$ of a reportable quantity or a permitted quantity, a FEMP is required for that facility. Check the appropriate space below.

FEMP is required _- FEMP is not required $x$

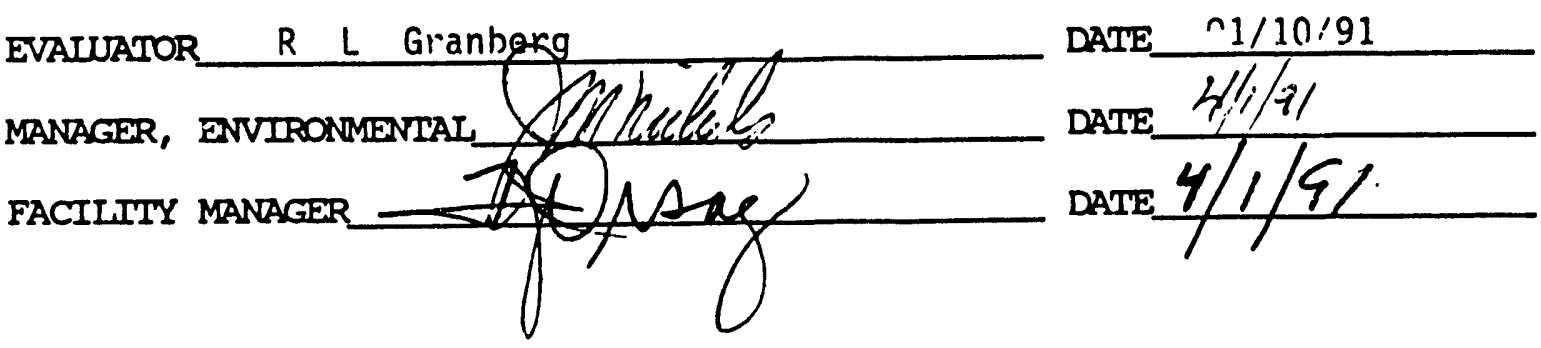


WHC-EP-0443

This page intentionally left blank. 
WHC-EP-0443

PART 3

616 FACILITY

FACILITY EFFLUENT MONITORING PLAN

DETERMINATION 
WHC-EP-0443

This page intentionally left blank. 
WHC-EP-0443

\section{CONTENTS}

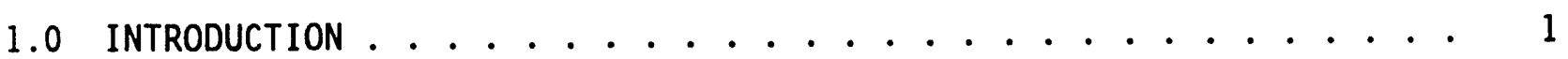

2.0 FACILITY DESCRIPTION/STATUS OF OPERATION ........... 1

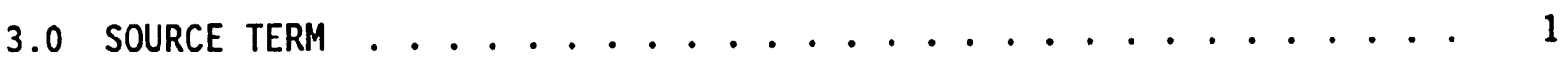

4.0 POTENTIAL UPSET-OPERATING CONDITIONS .............. 1

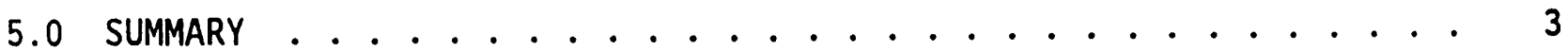

\section{ATTACHMENT}

1 DETERMINATION OF FACILITY EFFLUENT MONITORING PLAN

REQUIREMENT . . . . . . . . . . . . . . . Al-1 
WHC-EP-0443

This page intentionally left blank. 
WHC-EP-0443

\section{FACILITY}

\section{FACILITY EFFLUENT MONITORING PLAN DETERMINATION}

\subsection{INTRODUCTION}

A Facility Effluent Monitoring Plan (FEMP) is required for facilities that (1) contain quantities of radioactive materials that could cause radiation doses in excess of the required monitoring level specified in 40 Code of Federal Regulations (CFR) 61.93 (EPA 1989a) or (2) contain quantities of hazardous materials that exceed the reportable quantities listed in 40 CFR 302.4 (EPA 1989b). The criteria for hazardous materials can be relaxed if the facility can show that the maximum amount of hazardous materials released in any 12-mo period does not exceed a reportable quantity at the point of discharge.

\subsection{FACILITY DESCRIPTION/STATUS OF OPERATION}

The 616 Facility is located between the 200 East and 200 West Areas on the Hanford Site. The facility provides container storage for nonradioactive dangerous wastes generated in the research and development laboratories, process operations, and maintenance and transportation functions throughout the Hanford Site. Wastes are only stored at the facility until arrangements can be made to ship the waste to a permitted offsite treatment, storage, or disposal (TSD) facility. The unit was constructed to store up to 28,635 gal of nonradioactive dangerous waste in compliance with the Washington State Dangerous Waste Regulations (WAC 1989); however, administrative controls restrict this much waste from being stored at the facility at any given time. Storage of this waste is regulated under Washington Administrative Code (WAC) 173-303 (WAC 1989).

\subsection{SOURCE TERM}

\subsection{RADIOACTIVE MATERIALS}

There are no radioactive materials stored at the 616 Facility.

\subsection{HAZARDOUS MATERIALS}

Nonradioactive dangerous waste is stored by type of waste (oxidizer, caustic, combustible, acidic, Class A flammable, or Class $1 B$ flammable) in one of six storage cells within the unit. Each cell has a secondary containment system that includes curbing, fireproof walls, and a sloped concrete pad that drains to an 18-in. deep by 12-in. wide blind trench (there are no interior 
drains in any of the cells). To meet spill requirements, each secondary containment system is capable of holding at least $10 \%$ of the total volume of waste being stored within the cell.

All waste is containerized and packaged in accordance with U.S. Department of Transportation regulations. Daily inspections of the waste packages are performed by Operations personnel at the facility, while weekly inspections are performed by Engineering personnel. The building emergency plan details the procedures that need to be followed to ensure immediate response to a nonpermitted spill. However, the majority of spill response activities are performed by Hanford Fire Department personne1, who are located across the street from the 616 Facility.

Solid Waste Operations maintains an inventory at the 616 Facility which reflects the total waste on hand at a given time. The annual inventory is al so contained in DOE/RL-90-10 (DOE-RL 1990). This inventory currently is updated when waste is received (which is about two times a week) or when waste is shipped offsite (which is about twice a month). Information included in the inventory includes the hazardous material identification number, manifest number, drum number, shipping name, date received, and drum location. The inventory also indicates which wastes are identified as a reportable quantity item in accordance with 40 CFR 302.4 (EPA 1989b) regulations. The Hanford Fire Department is provided with updated inventories by close of business on days when the inventory changes.

Facility engineered controls (berms, trenches, etc.) limit the potential for a waste release to the environment since a spilled material would collect in the trench until removed. However, should a nonpermitted spill occur at the facility, the building emergency director, with support from other Hanford Site organizations, arranges for the TSD of the recovered waste. All soil, water, or other materials contaminated by a spill or discharge are treated, stored, or disposed of in accordance with WAC 173-303 (WAC 1989). The building emergency director activates any equipment necessary to perform this task and to protect public health and the environment.

As soon as possible after a spill situation, all cleanup debris and materials resulting from the incident are identified. If the spilled material is unknown, it is the responsibility of the building emergency director to coordinate the identification of the material. The building emergency director will, if necessary, collect and provide samples of the materials for onsite laboratory analyses to determine the hazards associated with handling them. The collected material also is designated in accordance with applicable standards of 40 CFR 261 (EPA 1989c) and WAC 173-303-070 (WAC 1989). After the released waste has been identified, cleanup of the affected area is initiated.

\subsection{POTENTIAL UPSET-OPERATING CONDITIONS}

Upset conditions were reviewed and considered for the hazardous materials stored at the facility. From these conditions it was determined that the worst-case scenario would result if a fire existed within one of the cells. However, due to total containment of the waste within each cell, fireproof walls, sloped curbing, negative pressure ventilation systems, a spill response 
team location, and administrative controls in place for flammable and/or reactive wastes, it is believed that a hazardous material release to the environment that exceeds a reportable quantity level would be very unlikely.

\subsection{SUMMARY}

Since there are no radioactive materials stored at the 616 Facility or processes that could release an excess of a reportable quantity of hazardous material to the environment, it was determined that a FEMP will not be required for the facility.

\subsection{REFERENCES}

DOE-RL, 1990, Hanford Site Annual Dangerous Waste Report - Volumes 1-5, DOE/RL-90-10, U.S. Department of Energy Field Office, Richland, Washington.

EPA, 1989a, "National Emission Standards for Hazardous Air Pollutants," Title 40, Code of Federal Regulations, Part 61, U.S. Environmental Protection Agency, Washington, D.C.

EPA, 1989b, "Designation, Reportable Quantities, and Notification," Title 40, Code of Federal Regulations, Part 302, U.S. Environmental Protection Agency, Washington, D.C.

EPA, 1989c, "Identification and Listing of Hazardous Waste," Title 40, Code of Federal Regulations, Part 261, U.S. Environmental Protection Agency, Washington, D.C.

WAC, 1989, Dangerous Waste Regulations, Washington Administrative Code 173-303, Washington State Department of Ecology, 01ympia, Washington. 
WHC-EP-0443

This page intentionally left blank. 
WHC-EP-0443

ATTACHMENT 1

DETERMINATION OF FACILITY EFFLUENT MONITORING PLAN REQUIREMENT

A1-1 
WHC-EP-0443

This page intentionally left blank. 


\section{ATTACHMENT 1}

\section{DETERMINATION OF FACILITY EFFLUENT MONITORING PLAN REQUIREMENT}

FACILITY 616 Unit

DISCHARGE POINT None

FACILITY INVENTORY AT RISK OF RADIOACTIVE MATERIALS:

There are no radioactive materials present at the 616 Unit.

\section{FACILITY INVENTORY AT RISK OF NONRADIOACTIVE HAZARDOUS MATERIALS:}

The inventory of nonradioactive hazardous materials is contained in the Hanford Site Annual Dangerous Waste Report - Volumes 1-5 (DOE-RL 1990). Information from this report identifies all nonradioactive waste which was processed through the unit, along with the weights of each item. Since all nonradioactive hazardous materials are contained at the unit and not released to the environment, the quantity released to the environment for eash item is 0 .

\section{Identification of Reference Material}

DOE/RL-90-10 (DOE-RL 1990)

If the total projected dose from radionuclides exceeds 0.1 mrem ede from any one discharge point or if any one regulated material discharged from a facility exceeds $10 \%$ of a reportable quantity or a permitted quantity, a FEMP is required for that facility. Check the appropriate space below.

FEMP is required

FEMP is not required
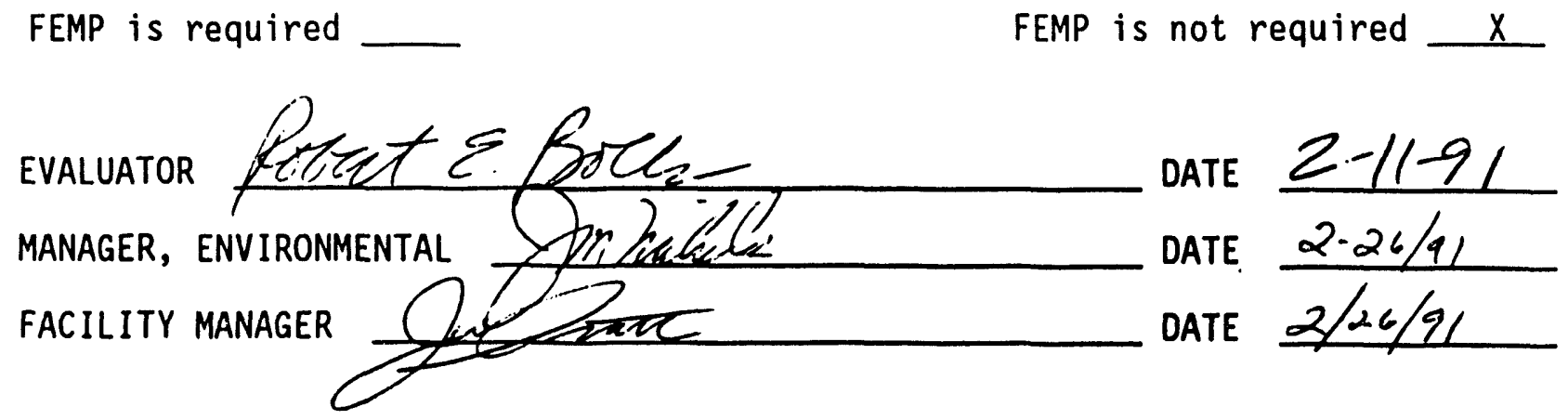
WHC-EP-0443

This page intentionally left blank. 
WHC-EP-0443

\section{PART 4}

\section{3-J\&K STORAGE VAULTS}

\section{FACILITY EFFLUENT MONITORING PLAN DETERMINATION}


WHC-EP-0443

This page intentionally left blank. 
WHC-EP-0443

\section{CONTENTS}

1.0 INTRODUCTION . . . . . . . . . . . . . . . . . . . . . . 1

2.0 FACILITY DESCRIPTION/STATUS OF OPERATION . . . . . . . . . . 1

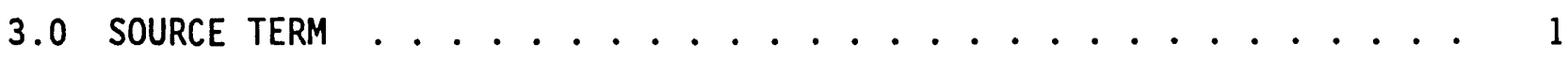

4.0 POTENTIAL UPSET-OPERATING CONDITIONS . . . . . . . . . . . . . 1

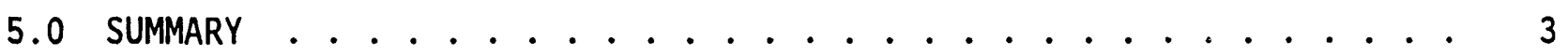

ATTACHMENT

1 DETERMINATION OF FACILITY EFFLUENT MONITORING PLAN

REQUIREMENT . . . . . . . . . . . . . . . . . . . Al-1 
WHC-EP-0443

\section{LIST OF FIGURES}

1 213-J\&K Storage Facility . . . . . . . . . . . . . . . . 2 
WHC-EP-0443

\section{3-J\&K STORAGE VAULTS}

\section{FACILITY EFFLUENT MONITORING PLAN DETERMINATION}

\subsection{INTRODUCTION}

This report determines if a Facility Effluent Monitoring Plan (FEMP) is required for the 213-j\&K Storage Vaults located in the 600 Area of the Hanford site. This facility is divided into two sections and is used only for material storage. One side of the facility (vault $K$ ) currently is being used to store nuclear-grade metallic sodium contained in 55-gal drums for Westinghouse Hanford Company. Each drum is stored in a nitrogen atmosphere. The drums were placed in storage on June 7, 1983. Pacific Northwest Laboratory uses the other half of the facility (vault J) to store soil samples that have been obtained from outside the Hanford Site.

\subsection{FACILITY DESCRIPTION/STATUS OF OPERATION}

The 213-J\&K Storage Vaults are located at the base of Gable Mountain in the 600 Area. Their primary function is for storage only; the vaults neither have the potential to generate radioactive airborne effluents nor generate hazardous airborne, radioactive liquids, or hazardous liquid effluents.

The 213-J\&K Storage Vaults are $40 \mathrm{ft}$ long by $18 \mathrm{ft}$ wide, as shown in Figure 1. Construction was completed in 1945. Ventilation for the facility is passive for both sides of the vault. Although the facility does have a powered ventilation system with high-efficiency particulate air filters, this unit has been taken out of service.

\subsection{SOURCE TERM}

Based on a review of the materials present in the 213-J\&K facility, the inventory-at-risk for routine and upset conditions is the 55-gal drums of nuclear-grade metallic sodium ( $99.99 \%$ sodium purity) located in the $K$ vault. In the event an accident should occur and containment is breached from the 55-gal drums, the metallic sodium would be contained by the secondary containment within the facility. However, when metallic sodium is exposed to moisture it becomes extremely reactive, resulting in detonation of the material. Metallic sodium is classified as a reactive metal.

\subsection{POTENTIAL UPSET-OPERATING CONDITIONS}

No potential upset conditions have been identified or deemed credible. 
WHC-EP-0443

Figure 1. 213-J\&K Storage Facility.

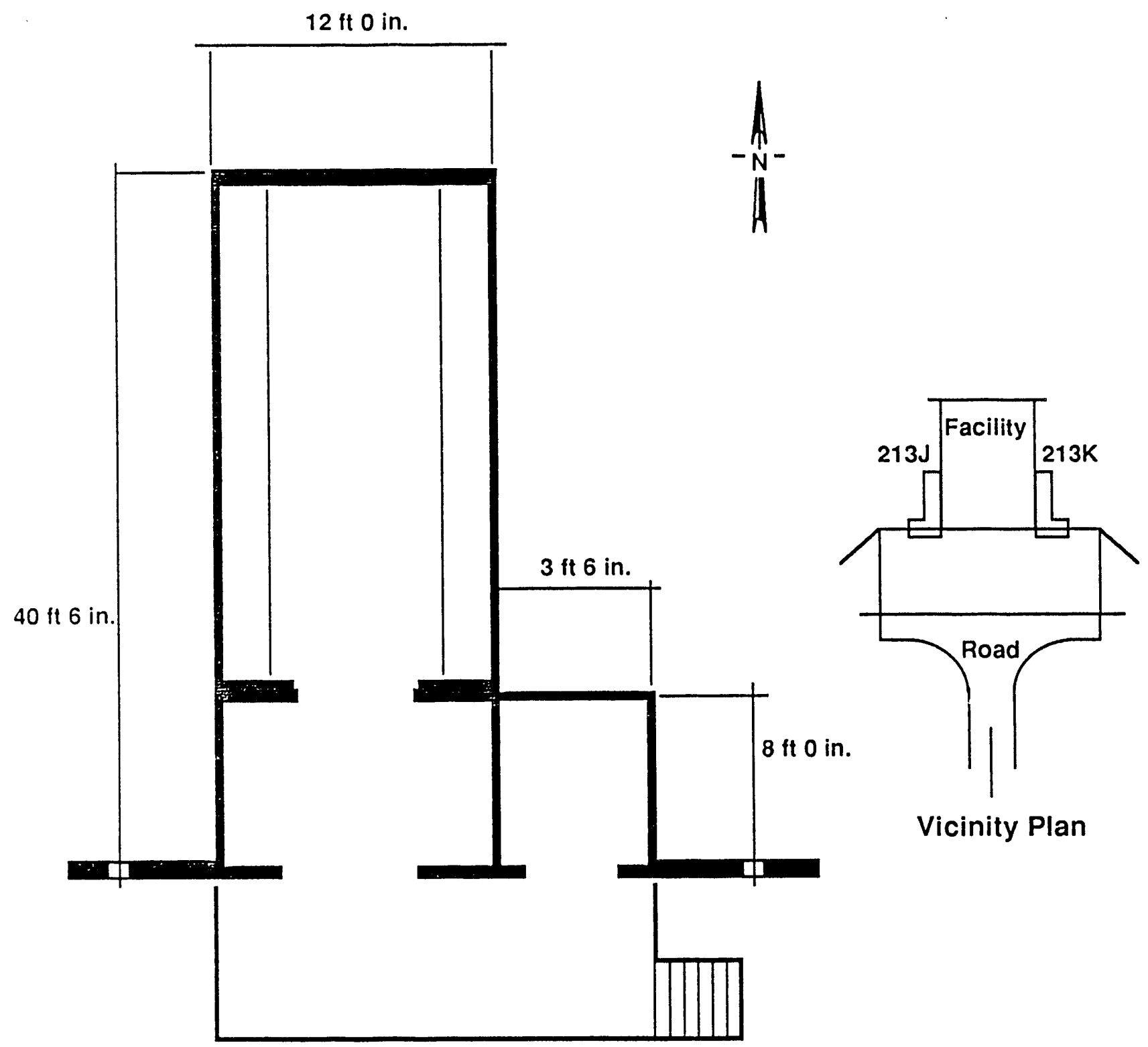

Floor Plan

29106008.5 


\subsection{SUMMARY}

Based on the information collected and data reviewed, a FEMP will not be required for the 213-J\&K Facility. This determination considered hazardous materials present during routine and upset-operating conditions and the potential release for airborne and liquid effluent pathways. 
WHC-EP-0443

This page intentionally left blank. 
WHC-EP-0443

\section{ATTACHMENT 1}

DETERMINATION OF FACILITY EFFLUENT MONITORING PLAN REQUIREMENT 
WHC-EP-0443

This page intentionally left blank. 


\section{ATTACHMENT 1}

DETERMINATION OF FACILITY EFFLUENT

MONITORING PLAN REQUIREMENT

FACILITY 213-J\&K/600 Area

DISCHARGE POINT N/A

\section{FACILITY INVENTORY AT RISK OF RADIOACTIVE MATERIALS}

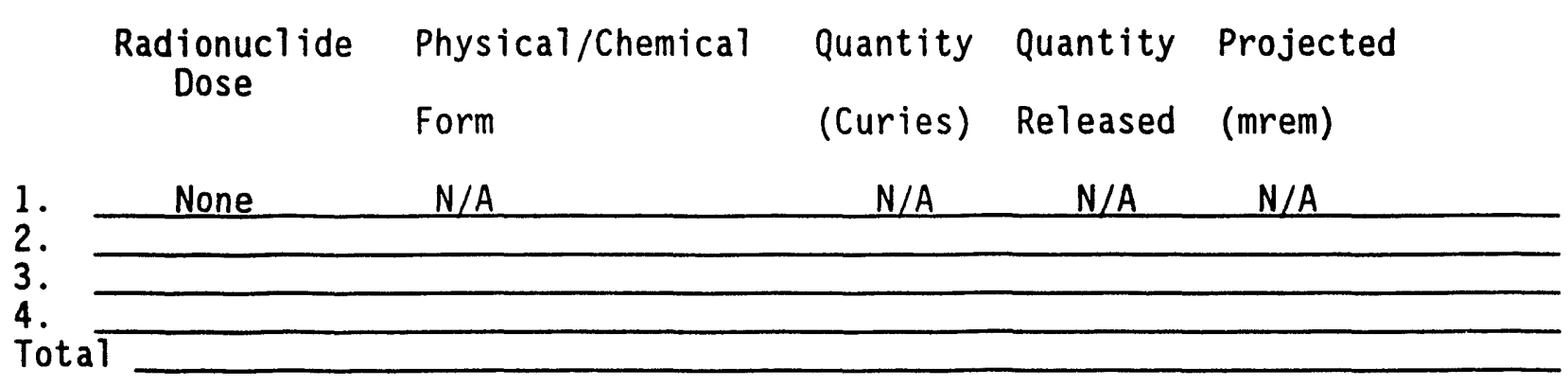

FACILITY INVENTORY AT RISK OF NONRADIOACTIVE HAZARDOUS MATERIALS

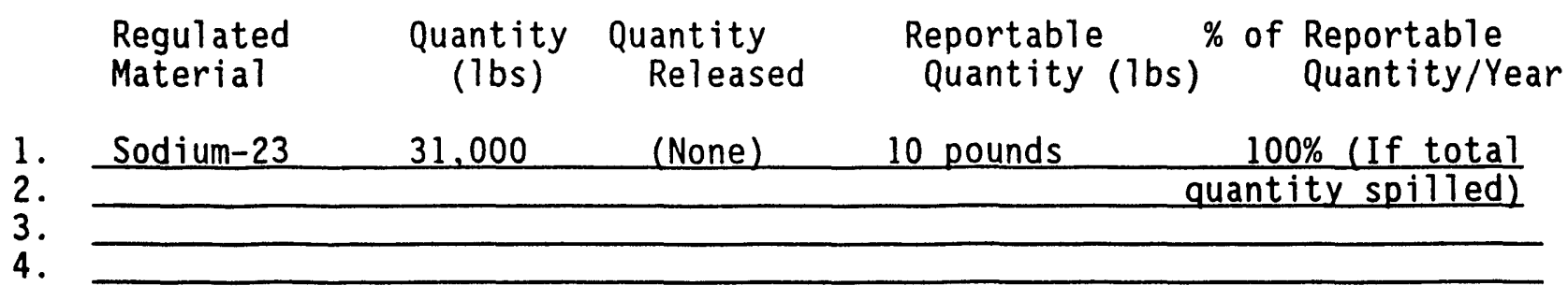

\section{Identification of Reference Material}

Material Safety Data Sheet (MSDS) No. 2059

SARA III Inventory

If the total projected dose from radionuclide exceeds 0.1 mrem EDE from any one discharge point or if any one regulated material discharged from a facility exceeds $100 \%$ of a reportable quantity or a permitted quantity, a FEMP is required for that facility. Check the appropriate space below.

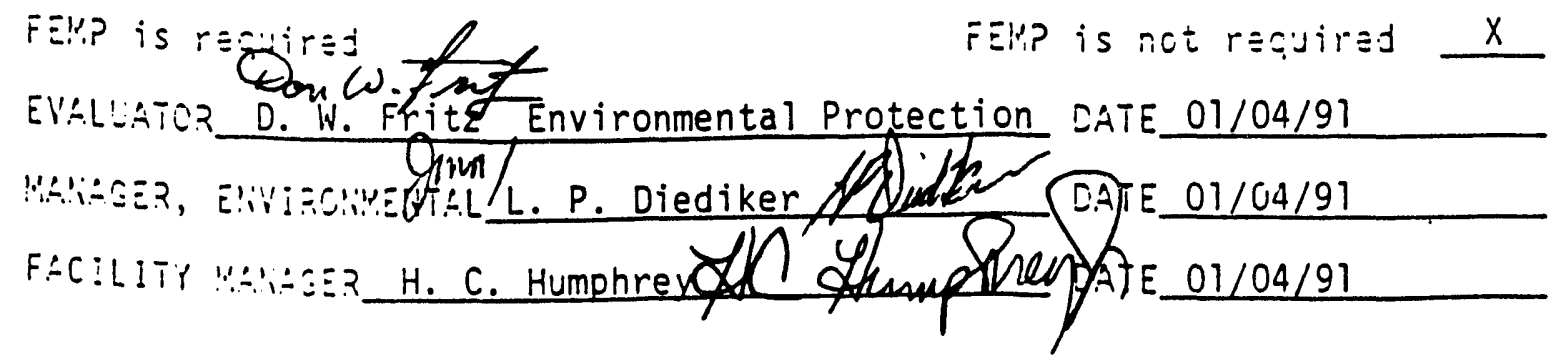


WHC-EP-0443

This page intentionally left blank.

Al-4 
WHC-EP-0443

APPENDIX A

UNIT DOSE CONVERSION FACTORS PREPARED BY PACIFIC NORTHWEST LABORATORY TO BE USED IN OFFSITE DOSE CALCULATIONS 
WHC-EP-0443

This page intentionally left blank. 
WHC-EP-0443

UNIT DOSE CALCULATIONS FOR WHC FACILITY EFFLUENT MONITORING PLANS

K. Rhoads

January 3, 1991

\section{INTRODUCTION}

Dose calculations for unit ( $1 \mathrm{C} i$ ) radionuclide releases were performed in support of efforts by Westinghouse Hanford Company (WHC) to develop Effluent Monitoring Plans for all WHC facilities on the Hanford site. Atmospheric releases from generic locations in the 100, $200 \mathrm{E}, 200 \mathrm{~W}$, and 300 areas were modeled for both elevated and ground-level releases; 400 area releases were modeled for ground level only. Impacts of liquid releases were evaluated for individuals at Ringold ( 100 and 200 area effluents) and Riverview (300 Area effluents). Both the CAP-88 (Beres 1990) and GENII (Napier et al 1988) code packages were used to model atmospheric releases in order to satisfy

requirements of the U. S. Environmental Protection Agency (USEPA 1989) and the U. S. Department of Energy. The GENII code was used to model liquid releases.

\section{METHODS}

Standard parameters for Hanford dose calculations were included in the calculations where possible (McCormack, et al 1984). Meteorology data were collected at weather stations in each of the Hanford operating areas and represent the five-year average of data taken between 1983 and 1987 . The location of the maximally exposed individual for each area is included in the attached tables with results of the dose calculations. Individual locations were based on the site boundary location having the greatest radionuclide air concentration under average atmospheric conditions. Doses were calculated as 50-year committed effective dose equivalents for all internal deposition pathways using the EPA model specified in 40 CFR 61. Default solubility classes were used for all radionuclides in these preliminary calculations. These should be appropriate for most facilities evaluated, except where plutonium or uranium are released in soluble form and contribute substantially to the overall dose from a given facility. Default classes for uranium and plutonium assume these radionuclides are released as insoluble compounds; this will result in a lower overall dose than would be the case if they were released in more soluble form.

\section{RESULTS}

Results of the evaluation are presented in Tables $1-11$, and represent the 50-year committed dose equivalent following a chronic annual release of $1 \mathrm{Cl}$ of each radionuclide. The CAP-88 and GENII codes handle ingrowth of longlived radioactive daughter products differently, as noted in the tables. GENII calculates doses for all radionuclides in each decay chain, therefore the doses reported in Tables $1-6$ include contributions from both parent and ingrown daughters. CAP-88 does not calculate activities for ingrowth of daughter radionuclides following release of the parent, but will estimate the dose from very short-lived daughters where the parent-to-daughter activity ratio is effectively $1: 1$. CAP-88 doses reported in Tables $7-11$ are for the parent nuclide only, except in the case where very short-lived daughters have been included in the parent dose as noted. CAP-88 doses including contributions from daughter ingrowth should be estimated using the fractional contribution from the parent nuclide reported in the GENII results. 
The total dose expected from emissions at a given facility can be obtained by multiplying the release quantity in $\mathrm{Ci}$ for each radionuclide by the corresponding unit dose factor in the tables, and summing the contributions for all nuclides in the effluent stream. Please note that doses calculated using the GENII code are reported as rem to the maximum individual from an annual release; those from CAP-88 are reported in mrem. Values in the tables were taken directly from code outputs, and have been left in the units reported by each code to avoid transcription errors.

\section{REFERENCES}

Beres, D. A., 1990. The Clean Air Act Assessment Package - 1988 (CAP-88). A Dose and Risk Assessment Methodology for Radionuclide Emissions to Air. Vols. 1-3, U. S. Environmental Protection Agency, Washington, D. C.

McCormack, W. D., J. V. Ramsde11, and B. A. Napier. 1984. Hanford Dose Overview Program: Standardized Methods and Data for Hanford Environmental Dose Calculations. PNL-3777, Rev. 1, Pacific Northwest Laboratory, Richland, Washington.

Napier, B. A., R. A. Peloquin, D. L. Strenge, and J. V. Ramsdel1. 1988. GENII - The Hanford Environmental Radiation Dosimetry Software System. PNL-6584, Vots. 1-3. Pacific Northwest Laboratory, Richland, Washington.

U. S. Environmental Protection Agency. 1989. National Emission Standards for Hazardous Air Pollutants: Radionuclides: Final Rule and Notice of Reconsideration. 40 CFR Part 61, Federal Register 54 (240):51654-51715. 
TAR!E 2. GENII DOSE ESTIMATES FOR 1 Ci RADIONUCLIDE RELEASES - 200 E AREA Location to the individual: 16000 METERS EAST

GROUND LEVEL
NUCLIDE DOSE EOUIVALENT (REM *

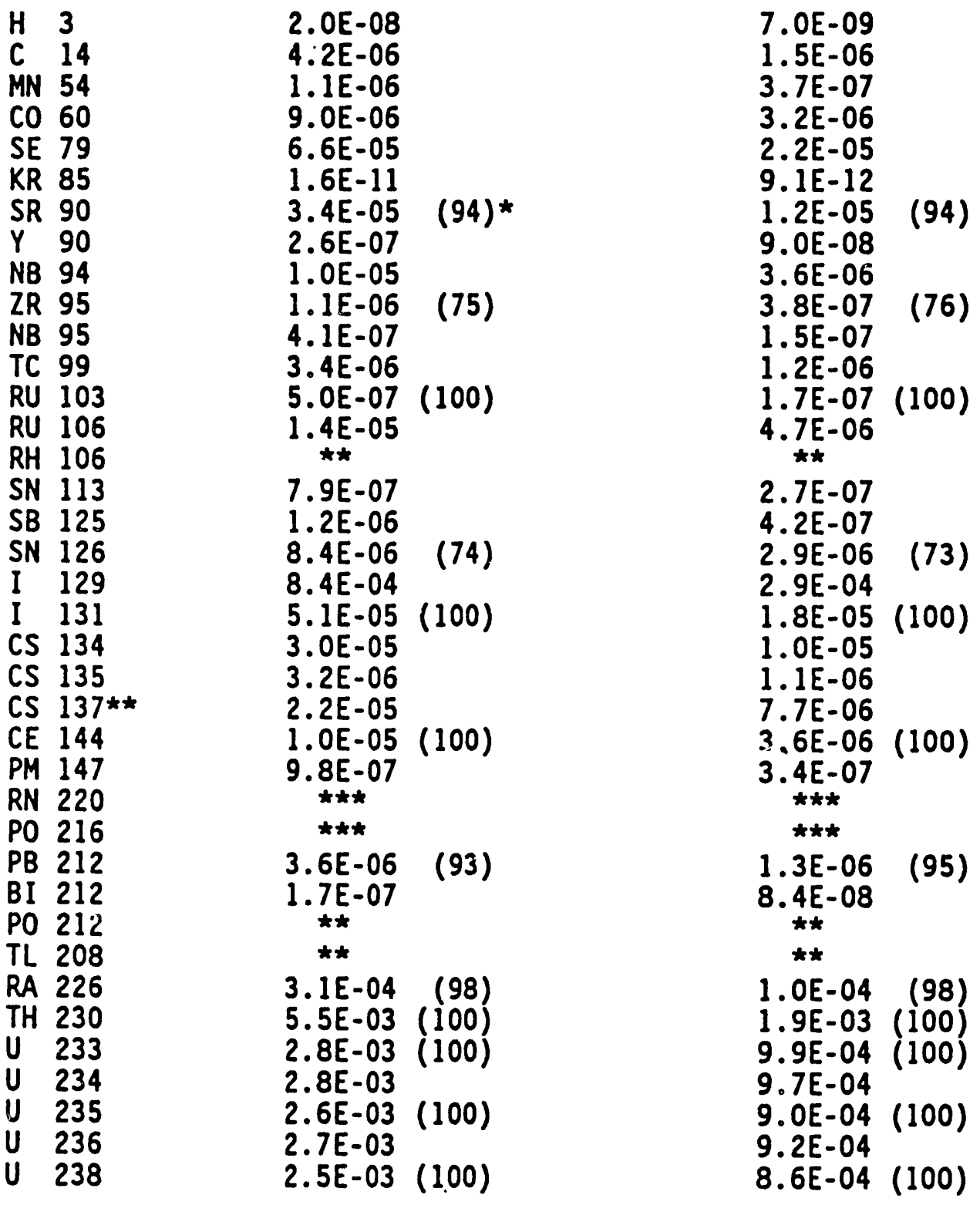

* Doses calculated with GENII include contributions from the parent nuclide, long-lived daughter chains, and short-lived daughters. Numbers in parenthesis indicate percent of the total dose attributable to the parent nuclide in chains with long-lived daughters.

** Short-lived daughters are included in dose from parent nuclide.

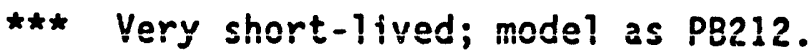


TABLE 2. GENII DOSE ESTIMATES FOR $1 \mathrm{Ci}$ RADIONUCLIDE RELEASES - 200 E AREA (Cont.) Location to the individual: 16000 METERS EAST

\begin{tabular}{|c|c|c|}
\hline NUCLIDE & $\begin{array}{l}\text { GROUND LEVEL } \\
\text { DOSE EOUIVALENT (REM) * }\end{array}$ & $\begin{array}{l}89 \mathrm{~m} \text { STACK } \\
\text { DOSE EOUIVALENT (REM }\end{array}$ \\
\hline $\begin{array}{ll}\text { NP } & 237 \\
\text { PU } & 238 \\
\text { PU } & 239 \\
\text { PU } & 240 \\
\text { FU } & 241 \\
\text { AM } & 241 \\
\text { AM } & 243 \\
\text { CM } & 244\end{array}$ & 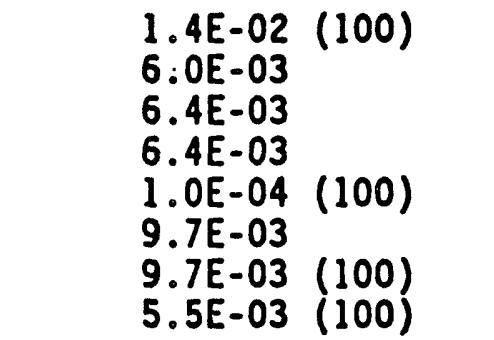 & $\begin{array}{l}5.0 E-03 \\
2.1 E-03 \\
2.2 E-03 \\
2.2 E-00) \\
2.2 E-03 \\
3.6 E-05 \quad(100) \\
3.4 E-03 \\
3.4 E-03 \quad(100) \\
1.9 E-03(100)\end{array}$ \\
\hline
\end{tabular}

* Doses calculated with GENII include contributions from the parent nuclide, long-lived daughter chains, and short-lived daughters. Numbers in parenthesis indicate percent of the total dose attributable to the parent nuclide in chains with long-lived daughters. 
TABLE 3. GENII DOSE ESTIMATES FOR $1 \mathrm{Ci}$ RADIONUCLIDE RELEASES - $200 \mathrm{~W}$ AREA Location to the individual: 24000 METERS EAST

\begin{tabular}{|c|c|c|}
\hline & $\begin{array}{l}\text { GROUND LEVEL } \\
\text { DOSE EOUIVALENT (REM)* }\end{array}$ & $\begin{array}{ll} & 89 \mathrm{~m} \text { STACK } \\
\text { DOSE EOUIVALENT }\end{array}$ \\
\hline
\end{tabular}

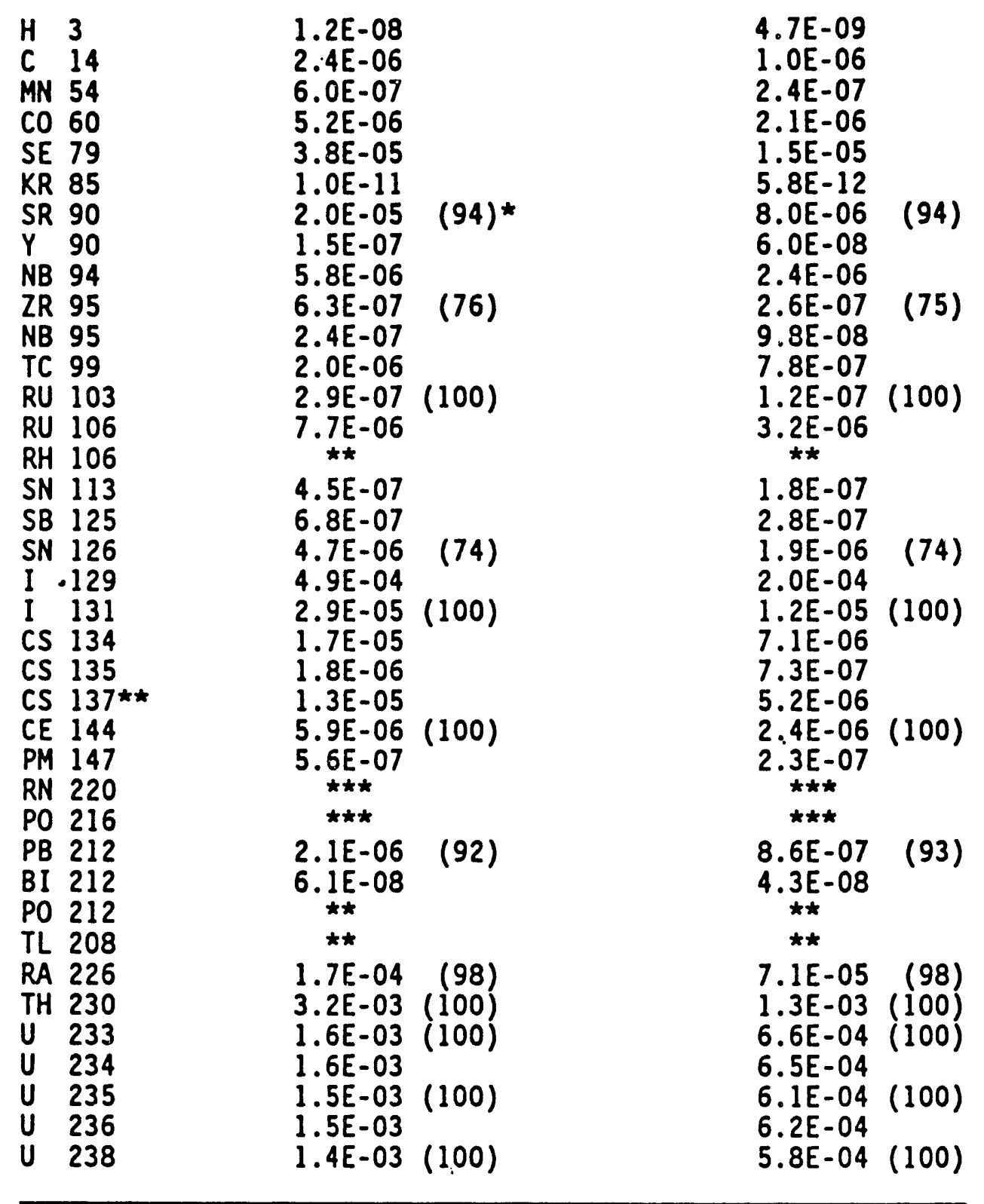

* Doses calculated with GENII include contributions from the parent nuclide, long-lived daughter chains, and short-lived daughters. Numbers in parenthesis indicate percent of the total dose attributable to the parent nuclide in chains with long-lived daughters.

** Short-lived daughters are included in dose from parent nuclide.

*** Very short-lived; model as PB212. 
TABLE 3. GENII DOSE ESTIMATES FOR $1 \mathrm{Ci}$ RADIONUCLIDE RELEASES - $200 \mathrm{~W}$ AREA

(Cont.) Location to the individual: 24000 METERS EAST

GROUND LEVEL

NUCLIDE DOSE EOUIVALENT (REM)*

89 m STACK

NP 237

PU 238

8.1E-03 (100)

3. $4 \mathrm{E}-03$

$3.6 \mathrm{E}-03$

$3.6 \mathrm{E}-03$

5.9E-05 (100)

5.6E-03

$(100)$

5.6E-03 (100)

3.2E-03 (100)

DOSE EOUIVALENT (REM)*

AM 241

AM 243

CM 244

3. 3E-03 (100)

$1.4 E-03$

$1.5 \mathrm{E}-03$

$1.5 \mathrm{E}-03$

2.4E-05 (100)

2.3E-03

2.3E-03 (100)

$1.3 E-03$ (100)

* Doses calculated with GENII include contributions from the parent nuclide, long-lived daughter chains, and short-lived daughters. Numbers in parenthesis indicate percent of the total dose attributable to the parent nuclide in chains with long-lived daughters. 
TABLE 8. CAP-88 DOSE ESTIMATES FOR 1 CI RADIONUCLIDE RELEASES - 200 E AREA Location to the individual: 16000 METERS EAST

$\begin{array}{ll}10 \mathrm{~m} \text { STACK } & 89 \mathrm{~m} \text { STACK } \\ \text { NUCLIDE DOSE EOUIVALENT (MREM)* DOSE EOUIVALENT (MREM) * }\end{array}$

\begin{tabular}{|c|c|c|}
\hline $\begin{array}{l}H-3 \\
C-14 \\
M N-54 \\
C O-60 \\
\text { SE-79 } \\
\text { KR-85 } \\
\text { SR-90 } \\
Y-90 \\
\text { NB-94 } \\
\text { ZR-95 } \\
\text { NB-95 } \\
T C-99 \\
R U-103 \\
R U-106 \\
R H-106 \\
\text { SN-113 } \\
\text { SB-125 } \\
\text { SN-126 } \\
I-129 \\
I-131 \\
C S-134 \\
C S-135 \\
C S-137 \star \star \star \\
C E-144 \\
P M-147 \\
R N-220 \\
P O-216 \\
P B-212 \\
B I-212 \\
P O-212 \\
T L-208 \\
R A-226 \\
T H-230 \\
U-233 \\
U-234 \\
U-235 \\
U-236 \\
U-238 \\
\text { Th }\end{array}$ & $\begin{array}{l}2.19 \mathrm{E}-05 \\
2.62 \mathrm{E}-03 \\
5.51 \mathrm{E}-03 \\
2.90 \mathrm{E}-02 \\
\star \star \\
4.88 \mathrm{E}-08 \\
4.38 \mathrm{E}-02 \\
3.77 \mathrm{E}-04 \\
2.58 \mathrm{E}-02 \\
2.65 \mathrm{E}-03 \\
1.76 \mathrm{E}-03 \\
1.09 \mathrm{E}-03 \\
1.42 \mathrm{E}-03 \\
2.09 \mathrm{E}-02 \\
\star \star \star \\
1.18 \mathrm{E}-03 \\
4.15 \mathrm{E}-03 \\
8.63 \mathrm{E}-03 \\
2.91 \mathrm{E}-01 \\
1.68 \mathrm{E}-02 \\
3.13 \mathrm{E}-02 \\
2.15 \mathrm{E}-03 \\
2.39 \mathrm{E}-02 \\
1.37 \mathrm{E}-02 \\
1.14 \mathrm{E}-03 \\
\star \star \star \star \\
\star \star \star \star \\
3.32 \mathrm{E}-03 \\
2.66 \mathrm{E}-04 \\
\star \star \star \\
\star \star \star \\
5.45 \mathrm{E}-01 \\
5.69 \mathrm{E}+00 \\
3.23 \mathrm{E}+00 \\
3.19 \mathrm{E}+00 \\
2.96 \mathrm{E}+00 \\
3.02 \mathrm{E}+00 \\
2.84 \mathrm{E}+00\end{array}$ & $\begin{array}{l}5.42 E-06 \\
6.48 E-04 \\
1.51 E-03 \\
7.94 E-03 \\
\star \star \\
1.21 E-08 \\
1.20 E-02 \\
1.04 E-04 \\
7.05 E-03 \\
7.24 E-04 \\
4.82 E-04 \\
2.97 E-04 \\
3.89 E-04 \\
5.71 E-03 \\
\star \star \star \\
3.23 E-04 \\
1.14 E-03 \\
2.36 E-03 \\
1.84 E-01 \\
1.06 E-02 \\
8.56 E-03 \\
5.87 E-04 \\
6.54 E-03 \\
3.75 E-03 \\
3.11 E-04 \\
\star \star \star \star \\
\star \star \star \star \\
9.42 E-04 \\
1.14 E-04 \\
\star \star \star \\
\star \star \star \\
1.49 E-01 \\
1.55 E+00 \\
8.83 E-01 \\
8.72 E-01 \\
8.10 E-01 \\
8.26 E-01 \\
7.77 E-01\end{array}$ \\
\hline
\end{tabular}

* Doses calculated with CAP88 are for the parent nuclide only, and do not include contributions from long-lived daughter chains.

* Dose factors not included in code radionuclide library.

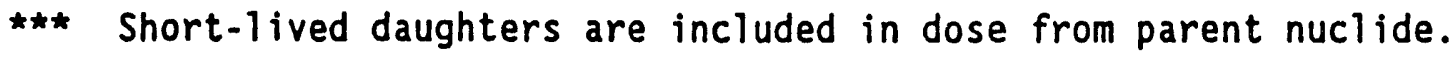

tht: Very short-lived; model as PBalz. 
TABLE 8. CAP-88 DOSE ESTIMATES FOR 1 Ci RADIONUCLIDE RELEASES - 200 E AREA (Cont.) Location to the individual: 16000 METERS EAST

\begin{tabular}{lrr} 
NUCLIDE & $10 \mathrm{~m}$ STACK & $89 \mathrm{~m}$ STACK \\
\hline NP -237 & $1.19 E+01$ & DOSE EQUIVALENT \\
PU-238 & $8.02 E+00$ & $3.25 E+00$ \\
PU-239 & $8.67 E+00$ & $2.19 E+00$ \\
PU-240 & $8.66 E+00$ & $2.37 E+00$ \\
PU-241 & $1.38 E-01$ & $2.37 E+00$ \\
AM-241 & $1.31 E+01$ & $3.76 E-02$ \\
AM-243 & $1.31 E+01$ & $3.59 E+00$ \\
CM-244 & $6.94 E+00$ & $3.59 E+00$ \\
& & $1.90 E+00$
\end{tabular}

* Doses calculated with CAP88 are for the parent nuclide only, and do not include contributions from long-lived daughter chains. 
TABLE 9. CAP-88 DOSE ESTIMATES FOR 1 CI RADIONUCLIDE RELEASES - 200 W AREA Location to the individual: 24000 METERS EAST

$10 \mathrm{~m}$ STACK
NUCLIDE DOSE EQUIVALENT (MREM)*

\begin{tabular}{|c|c|c|}
\hline $\begin{array}{l}H-3 \\
C-14 \\
M N-54 \\
C O-60 \\
S E-79\end{array}$ & $\begin{array}{c}1.38 E-05 \\
1.65 E-03 \\
3.27 E-03 \\
1.72 E-02 \\
\star \star\end{array}$ & $\begin{array}{c}3.58 E-06 \\
4.28 E-04 \\
9.84 E-04 \\
5.19 E-03 \\
\star \star\end{array}$ \\
\hline $\begin{array}{l}K R-85 \\
\text { SR-90 } \\
Y-90 \\
N B-94 \\
Z R-95 \\
N B-95 \\
T C-99 \\
R U-103 \\
R U-106 \\
R H-106\end{array}$ & $\begin{array}{l}3.07 E-08 \\
2.60 E-02 \\
2.22 E-04 \\
1.53 E-02 \\
1.57 E-03 \\
1.05 E-03 \\
6.45 E-04 \\
8.45 E-04 \\
1.24 E-02 \\
\star \star \star\end{array}$ & $\begin{array}{l}7.98 \mathrm{E}-09 \\
7.82 \mathrm{E}-03 \\
6.73 \mathrm{E}-05 \\
4.61 \mathrm{E}-03 \\
4.73 \mathrm{E}-04 \\
3.15 \mathrm{E}-04 \\
1.94 \mathrm{E}-04 \\
2.54 \mathrm{E}-04 \\
3.73 \mathrm{E}-03 \\
\star \star \star\end{array}$ \\
\hline $\begin{array}{l}S N-113 \\
S B-125 \\
S N-126 \\
I-129 \\
I-131 \\
C S-134 \\
C S-135 \\
C S-137 \star \star \star \\
C E-144 \\
P M-147 \\
\text { RN-220 } \\
P O-216\end{array}$ & $\begin{array}{l}7.02 E-04 \\
2.47 E-03 \\
5.12 E-03 \\
1.14 E-01 \\
6.53 E-03 \\
1.86 E-02 \\
1.28 E-03 \\
1.42 E-02 \\
8.14 E-03 \\
6.75 E-04 \\
\star \star \star \star \\
\star \star \star \star\end{array}$ & $\begin{array}{l}2.11 \mathrm{E}-04 \\
7.42 \mathrm{E}-04 \\
1.54 \mathrm{E}-03 \\
1.09 \mathrm{E}-01 \\
6.29 \mathrm{E}-03 \\
5.60 \mathrm{E}-03 \\
3.84 \mathrm{E}-04 \\
4.28 \mathrm{E}-03 \\
2.45 \mathrm{E}-03 \\
2.03 \mathrm{E}-04 \\
\star \star \star \star \star \\
\star \star \star \star\end{array}$ \\
\hline $\begin{array}{l}P B-212 \\
B I-212 \\
P O-212 \\
T L-208\end{array}$ & $\begin{array}{l}1.85 E-03 \\
9.88 E-05 \\
\star \star \star \\
\star \star \star\end{array}$ & $\begin{array}{c}5.91 E-04 \\
5.81 E-05 \\
\star \star \star \\
\star \star \star\end{array}$ \\
\hline $\begin{array}{l}R A-226 \\
T H-230 \\
U-233 \\
U-234 \\
U-235 \\
U-236 \\
U-238\end{array}$ & $\begin{array}{l}3.23 E-01 \\
3.38 E+00 \\
1.92 E+00 \\
1.89 E+00 \\
1.76 E+00 \\
1.79 E+00 \\
1.69 E+00\end{array}$ & $\begin{array}{l}9.73 E-02 \\
1.02 E+00 \\
5.77 E-01 \\
5.70 E-01 \\
5.30 E-01 \\
5.40 E-01 \\
5.08 E-01\end{array}$ \\
\hline
\end{tabular}

* Doses calculated with CAP88 are for the parent nuclide only, and do not include contributions from long-lived daughter chains.

* Dose factors not included in code radionuclide library.

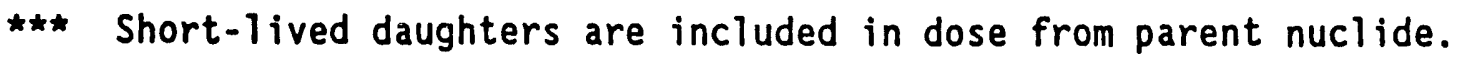

$\star \star \star \star$ Very short-1ived; model as PB212. 
WHC-EP-0443

TABLE 9. CAP-88 DOSE ESTIMATES FOR 1 Ci RADIONUCLIDE RELEASES - 200 W AREA (Cont.) Location to the individual: 24000 METERS EAST

10 m STACK

NUCLIDE DOSE EOUIVALENT (MREM)* DOSE EOUIVALENT (MREM)*

$N P-237$

PU-238

$7.05 E+00$

$2.12 E+00$

PU-239

PU -240

PU-241

AM-241

AM-243

CM-244

4.76E+00

$5.15 E+00$

$1.43 E+00$

$5.14 E+00$

8.17E-02

$7.79 E+00$

$7.79 E+00$

$4.12 E+00$

$1.55 E+00$

$1.55 \mathrm{E}+00$

2. $46 \mathrm{E}-02$

2. $35 \mathrm{E}+00$

2.34E+00

$1.24 E+00$

* Doses calculated with CAP88 are for the parent nuclide only, and do not include contributions from long-lived daughter chains. 
WHC-EP-0443

\section{DISTRIBUTION}

Number of Copies

OFFSITE

1

U.S. Environmental Protection Agency, Region $X$ 1200 Sixth Avenue

Seattle, Washington 98081

G. O'Neal

AT-081

1

U.S. Environmental Protection Agency, Region $X$

712 Swift Boulevard, Suite 5

Richland, Washington 99352

P. T. Day

2

Washington State Department of Health Radiation Protection Division

Airdustrial Park, Bldg. 5

0lympia, Washington 98504

A. Conklin

1

Westinghouse Idaho Nuclear Company

$$
\begin{aligned}
& \text { PO Box } 4000 \\
& \text { Idaho Falls, Idaho } 83403
\end{aligned}
$$

K. Kouri

$32-02$

ONSITE

8

U.S. Department of Energy Field Office, Richland
G. M. Be11
R. F. Brich
S. S. Clark
E. B. Dagan
L. A. Huffman
T. P. Pietrok
S. D. Stites
Public Reading Room
Hanford Environmental Health
Foundation

A5-52

A5- 55

A6-55

A5-19

A6-55

A5- 19

A5-19

Al-65

L. J. Maas

B2-75 
DISTRIBUTION (continued)

Number of Copies

ONSITE

1

Kaiser Engineers Hanford

P. G. Bodily

E2-10

7

Pacific Northwest Laboratory

W. J. Bjorklund

P7-68

T. D. Chikalla

P7 -75

R. E. Jaquish

$\mathrm{K} 1-30$

D. L. Klages

P7-68

A. K. Stalker

M. J. Sula

P7 -60

R. K. Woodruff

P7-78

Technical Files

K6-13

$\mathrm{K} 1-11$

41

Westinghouse Hanford Company

S. E. Albin

T1-06

S. M. Anthony

N3-05

R. J. Bliss

B3-04

R. E. Bolls

N3-13

M. J. Brown

T1-30

G. D. Carpenter

B2-16

G. J. Carter

T1-06

L. P. Diediker (2)

T1-30

J. J. Dorian

B2-16

J. A. Eacker

R1-51

D. G. Farwick

$\mathrm{H} 4-16$

K. A. Gano

X0-21

L. A. Garner

T5-54

E. M. Greager

L6-60

K. A. Hadley

$\mathrm{N} 1-35$

N. S. Hale

B4-53

M. J. Hall

B2-19

D. R. Herman

S4-01

K. R. Jordan

B3-51

E. J. Kosiancic

SO-61

R. J. Landon

B2 -19

R. E. Lerch

B2 -35

G. J. Miskho

J. M. Nickels (2)

R2-50

R. A. Paasch

T1 -30

M. M. Pereira

B2-20

K. N. Peterson

S6-70

D. R. Pratt

S6-70

R. J. Thompson

T1-30

R. R. Thompson

S6-01

L4-88 
WHC-EP-0443

\section{DISTRIBUTION (continued)}

Number of Copies

ONSITE

West inghouse Hanford Company (continued)

L. W. Vance

H4-16

D. J. Watson

C. D. Wollam

$\times 0-41$

Document Processing

and Distribution (2)

Central Files

S6-19

Information Release

Administration (3)

L8-15

L8-04

R1-08 
WHC-EP-0443

This page intentionally left blank.

Distr-4 

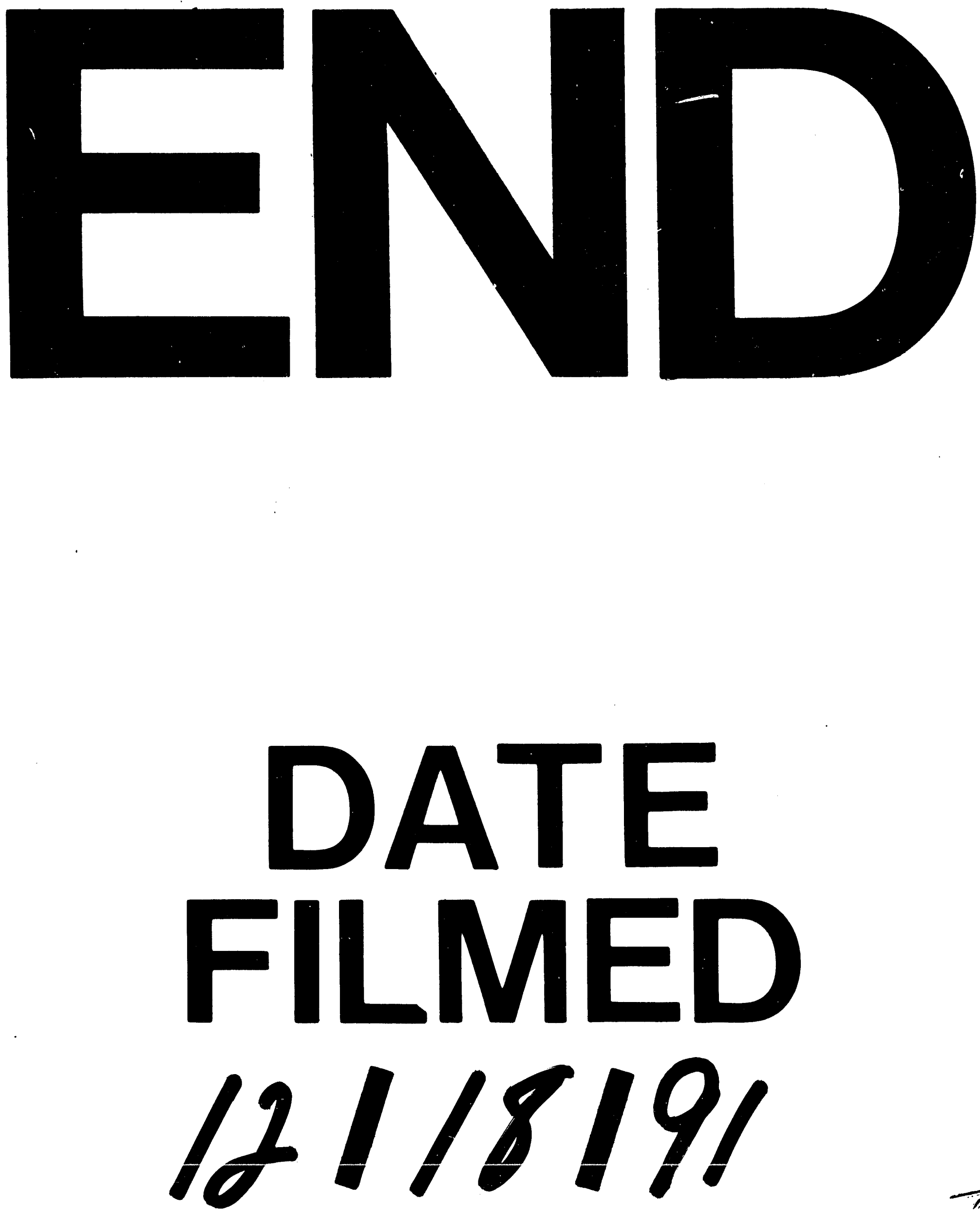

T" 
